\title{
Natural blue zircon from Vesuvius
}

\author{
Yi Sun $^{1,2}$ (D) Axel K. Schmitt ${ }^{1} \cdot$ Tobias Häger $^{3} \cdot$ Marcus Schneider $^{1} \cdot$ Lucia Pappalardo $^{4} \cdot$ Massimo Russo $^{4}$
}

Received: 31 March 2020 / Accepted: 15 October 2020 / Published online: 31 October 2020

(C) The Author(s) 2020

\begin{abstract}
Zircon from syenitic ejecta of Vesuvius (Campania, Italy) is unusually blue, a property shared with gem zircon from Ratanakiri province (Cambodia), which turns from natural reddish-brown to blue when heated under reducing conditions. Here, the origins of these unusual crystals were traced through geochronology, trace elements, and O-Hf isotopic compositions. The causes of its colour were investigated through optical and electron microscopy, optical absorption spectroscopy, and Raman microspectroscopy. Colour stability upon heating and ultraviolet light (UV) exposure was tested using Ratanakiri zircon as a control. Vesuvius zircon contains vesiculated zones with abundant inclusions $\sim 2.5 \mu \mathrm{m}$ to $<100 \mathrm{~nm}$ in diameter (mostly U-rich thorianite and pyrochlore-group minerals), while homogeneous zircon domains are high in Th and $\mathrm{U}$ (up to 5.9 and $1.8 \mathrm{wt} \%$, respectively). Its blue colouration is stable under $\mathrm{UV}$ radiation, as well as heat-treatment under reducing conditions $\left(1000^{\circ} \mathrm{C} ;>15 \mathrm{~h}\right)$. Turbid domains rich in large inclusions change to yellow-brown after heating under oxidizing conditions, while transparent domains remain pale blue or colourless. Optical absorption spectra display sharp absorption lines attributed to $\mathrm{U}^{4+}$, and slightly elevated absorption towards shorter wavelengths. The $\sim 1007 \mathrm{~cm}^{-1} v_{3}\left(\mathrm{SiO}_{4}\right)$ Raman band is broadened due to lattice distortion by non-stoichiometric elements in high-Th/-U zircon, whereas narrow bands in inclusion-rich domains indicate a decrease in lattice strain due to inclusion precipitation. Blue colouration in Vesuvius zircon is explained by the effect of light scattering (Rayleigh and/or Mie scattering) on highly refractive actinide-rich inclusions ranging in size from $<1 / 10$ to few multiples of the wavelengths of visible light. Inclusions likely formed during fluid-mediated coupled dissolution-reprecipitation that locally transformed lattice-strained actinide-rich zircon within several hundreds of years prior to eruption.
\end{abstract}

Keywords Blue zircon · Vesuvius · Rayleigh/Mie scattering · Optical absorption · Raman microspectroscopy $\cdot$ Mineral inclusions $\cdot$ Syenite

Editorial handling: L. Nasdala

Supplementary Information The online version of this article (https:// doi.org/10.1007/s00710-020-00727-7) contains supplementary material, which is available to authorized users.

Yi Sun

yi.sun@erdw.ethz.ch

1 Institute of Earth Sciences, Heidelberg University, Im Neuenheimer Feld 236, D-69120 Heidelberg, Germany

2 Present address: Institute of Geochemistry and Petrology, ETH Zürich, Clausiusstrasse 25, 8092 Zürich, Switzerland

3 Institute of Geosciences, Johannes Gutenberg University Mainz, J.-J.-Becher-Weg 21, D-55128 Mainz, Germany

4 Osservatorio Vesuviano, Istituto Nazionale di Geofisica e Vulcanologia, via Diocleziano 328, 80124 Naples, Italy

\section{Introduction}

Zircon $\left(\mathrm{ZrSiO}_{4}\right)$ is a common accessory mineral in crustal igneous and metamorphic rocks, which primarily originates in evolved felsic melts (e.g., granite, syenite); owing to its resistance against chemical and physical weathering, it is also widespread as a detrital phase in sedimentary settings (e.g., Deer et al. 1982; Faulkner and Shigley 1989). More rarely, zircon megacrysts occur in pegmatites or as xenocrysts in alkaline basalts and are used as gemstones due to their outstanding dispersion, reflective index and relative hardness (e.g., Faulkner and Shigley 1989; Zeug et al. 2018). While chemically pure zirconium orthosilicate is colourless, natural zircon typically shows structural imperfections such as incorporation of trace elements or radiation damage, resulting in varied colourations ranging from red, yellow, brown, green, purple and blue to black (Rossman 1981; Kempe et al. 2016; Zeug et al. 2018). 
Commercially marketed blue coloured gem zircon is generally artificially produced by heat-treatment of reddishbrown natural zircon crystals (Fig. 1 a) at temperatures of $\sim 1000{ }^{\circ} \mathrm{C}$ under reducing conditions for several hours (e.g., Satitkune et al. 2013; Wittwer et al. 2013; Zeug et al. 2018). Dark red-brown zircon crystals from the Bei Srok area (Ratanakiri province, Cambodia) are specifically susceptible to this colour change (Piilonen et al. 2018), although less intense blue colouration can also be achieved using raw material from other mines in Ratanakiri province (Piilonen et al. 2018) as well as from Chanthaburi and Kanchanaburi (Thailand; Satitkune et al. 2013; Zeug et al. 2018); Shan State (Myanmar; Zeug et al. 2018) or the Central Highlands (Vietnam; Huong et al. 2016). Also, the colour of dark green metamict zircon from Ratnapura (Sri Lanka) can be thermally enhanced to light blue by heat treatment under similar conditions (Rupasinghe and Senaratne 1986).

At present, there is no theory which can fully explain both (1) the colour change to blue induced by heating under
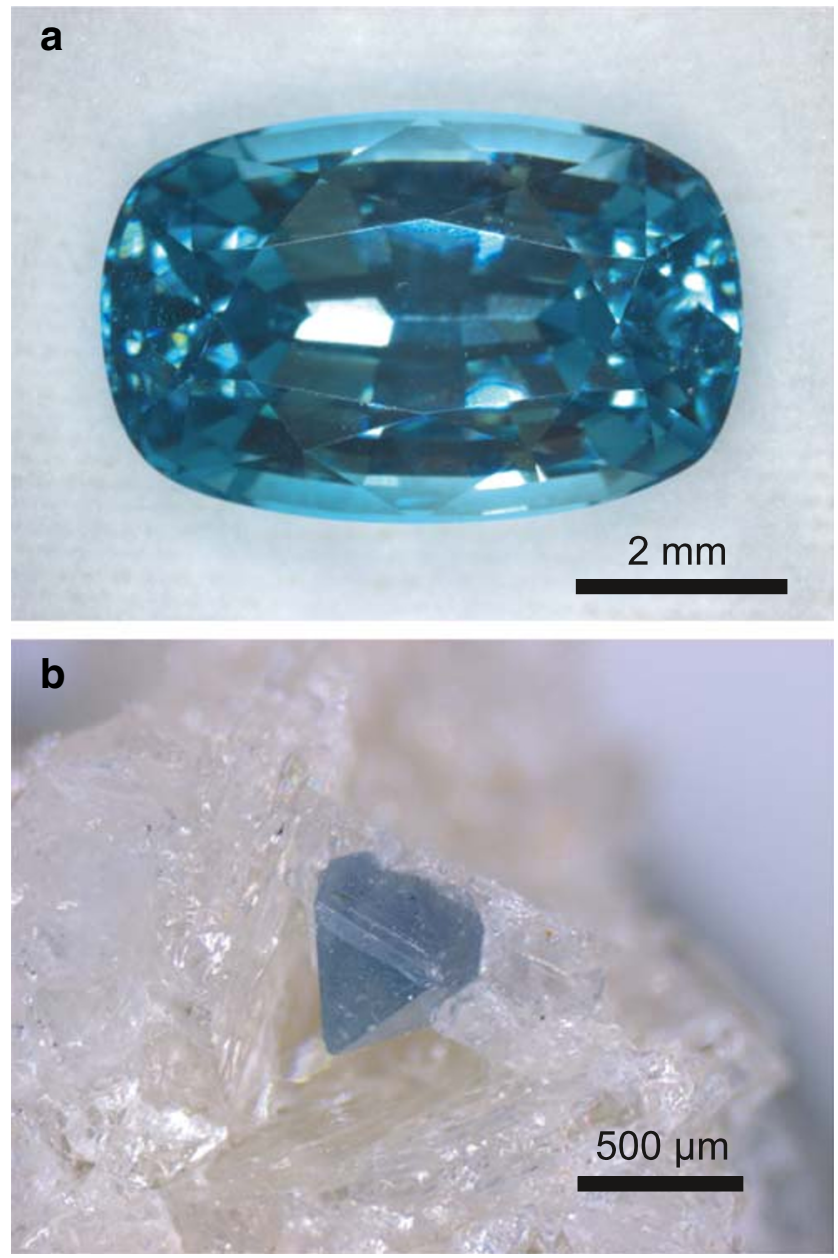

Fig. 1 Focus-stacked optical images of blue zircon crystals: a) heattreated blue zircon as a cut gemstone likely from Ratanakiri; b) natural blue Vesuvius zircon crystal growing in interstitial volumes between sanidine crystals, collected from the San Vito Quarry near Ercolano reduced conditions and (2) the special susceptibility of Ratanakiri brown zircon for this phenomenon (Zeug et al. 2018). While the presence of a broad absorption band centred at $\sim 640 \mathrm{~nm}$ was shown to be responsible for the blue colour of heated Ratanakiri zircon by optical spectroscopy, its attribution to a specific chromophore (e.g., $\mathrm{U}^{4+}, \mathrm{Tb}^{3+}$ ) is still problematic and controversially discussed (Zeug et al. 2018). Understanding the causes of blue colouration in zircon is of importance for optimization of the heat-treatment technique used and can help to improve the qualitative output of these heat-treated gemstones.

Blue zircon of unambiguously natural origin has only been reported for one occurrence: volcanic ejecta from the western flank of Vesuvius volcano (Campania, Italy; Russo and Punzo 2004; Kempe et al. 2016; Zeug et al. 2018). Kempe et al. (2016) suggested that reheating of early-formed zircon crystals by ascending magma during eruption might be responsible for the blue colour; thus Vesuvius blue zircon (Fig. 1 b; Fig. S1-S2 in the electronic supplementary material (ESM)) might represent a natural analogue for heat-treated Ratanakiritype gem zircon. Insufficient sample dimensions, however, prevented the acquisition of optical spectra (Kempe et al. 2016), and no further mineralogical characterization of Vesuvius blue zircon has been published yet. Here, we present the first comprehensive characterization of Vesuvius blue zircon (including quantitative chemical analysis of trace elements and O-Hf isotopes, geochronology, optical and electron microscopy, as well as optical absorption spectroscopy and Raman microspectroscopy) to determine the origin of these unusual crystals, while also proposing a previously undocumented mechanism for the blue colour of Vesuvius zircon that differs from that of heat-treated Ratanakiri zircon.

\section{Geological setting}

The Bronze Age Avellino pumice eruption $(3945 \pm 10 \mathrm{cal} \mathrm{BP}$; Sevink et al. 2011) represents one of the four major Plinian eruptions of Monte Somma-Vesuvius (Campania, Italy) during the last 22 ka BP (e.g., Di Renzo et al. 2007; Santacroce et al. 2008). The vent area of the Avellino pumice eruption was located at the Piano della Gianestre, and proximal pyroclastic fall deposits were deposited at the western flank of Somma-Vesuvius (Cioni et al. 1999; Linde et al. 2017). Accessory lithic ejecta, including nodules of subvolcanic syenite, cumulate rocks (e.g., pyroxenite) and skarns, are abundant in the central to upper stratigraphic units of the pyroclastic sequence (EU3-EU5; Sulpizio et al. 2010a, 2010b).

The syenitic ejecta originated from the crystalline carapace of the magma reservoir where they crystallized from highly fractionated melts or fluids in the uppermost, most evolved sections of the magma chamber (e.g., Fulignati et al. 2004). Magmatic temperatures are estimated as $\sim 1200{ }^{\circ} \mathrm{C}$ for the 
tephritic source magma, and $\sim 800^{\circ} \mathrm{C}$ for the highly evolved, phonolitic melts erupted during the Avellino eruption (Barberi et al. 1981; Balcone-Boissard et al. 2012). Extremely high zircon saturation levels $(\sim 12,000 \mathrm{ppm})$ are expected for the mafic, tephritic source melts of Vesuvius considering the conditions in the magma chamber $\left(\mathrm{T}=1200{ }^{\circ} \mathrm{C} ; P=0.2 \mathrm{GPa}\right.$; Balcone-Boissard et al. 2012) and equations by Shao et al. (2019), reinforcing a propensity for zircon to crystallize from their more felsic differentiates. Slightly oxidized magma conditions with oxygen fugacity $\left(f_{\mathrm{O} 2}\right)$ of +1.24 above the $\mathrm{Ni}-\mathrm{NiO}$ buffer (NNO) were calculated for Avellino phonolite using stable sulphur isotope ratios (Marini et al. 1998).

\section{Materials and methods}

\section{Sample material and thin-section petrography}

Two zircon-bearing syenite clasts were collected from the San Vito Quarry, Ercolano (40 49'50.91'”N - $14{ }^{\circ} 22^{\prime} 54.84 " \mathrm{E}$ ). The medium to coarse-grained syenite is porous (pore volume $\sim 10-30 \%$ ) with a granular isotropic texture and contains as a major constituent lath-shaped and idiomorphic sanidine crystals (Fig. 2 a) up to 2 mm length, often with Carlsbad twinning. Sodalite occurs as poikilitic crystals along with opaque Fe-Ti oxides and biotite forming subhedral crystals up to $2 \mathrm{~mm}$ in size (Fig. 2 a). Accessory apatite, fluorite, and members of the pyrochlore group are present as minute $(<500 \mu \mathrm{m})$, late-formed grains in interstitial volumes between the earlyformed sanidine.

Zircon crystals are euhedral to subhedral, translucent, and mostly $1-3 \mathrm{~mm}$ in diameter. They show a bipyramidal habit with dominating $\{101\}$ faces, which is typical for U- and Thenriched zircons (Kostov 1973). In reflected light, the zircon grains show weak pleochroism and are greyish blue to purplish blue with minor colourless, transparent domains. In transmitted light, they appear nearly colourless to light brown (Fig. 2 a). Tens of similar looking crystals were extracted from a single specimen ( $\sim 7 \mathrm{~cm}$ in diameter) of syenite; other Vesuvius syenite clasts contain zircon with identical appearance (Fig. S1-S2 in the ESM).

Brown alluvial zircon crystals from the Ratanakiri province (Cambodia) were included for comparative purposes during heating and irradiation experiments. In total, 13 waterworn crystals 5-10 $\mathrm{mm}$ in diameter were studied.

\section{Sample preparation}

Vesuvius zircon crystals were separated from the syenite groundmass by gentle grinding in an agate mortar and handpicking under a stereo microscope. Twenty selected crystals (200-800 $\mu \mathrm{m}$ in diameter) were mounted in epoxy with grains of reference zircon samples AS3 and 91,500. This mount (Erc-z1) was ground and polished with SiC grinding paper $(5 \mu \mathrm{m})$ and diamond polishing paste $(0.25 \mu \mathrm{m})$. In addition, multiple grains of both untreated and heat-treated Vesuvius and Ratanakiri zircon were selected for optical investigation
Fig. 2 Optical appearance and microtextures of natural Vesuvius zircon grains: a) thin section of a syenitic ejecta in transmitted light showing the petrographic relationship between subhedral zircon ( $\mathrm{Zrn})$, sanidine (Sa) and biotite $(\mathrm{Bt}) ; \mathrm{b})$ back-scattered electron (BSE) image showing oscillatory and sector zoning in natural Vesuvius zircon; $\mathrm{c}$ and $\mathrm{d}$ ) high magnification BSE images of Th-U-rich inclusions and pore volumes in Vesuvius zircon; both samples were heat-treated under oxidizing conditions, but no textural difference was observed between natural and unheated zircon
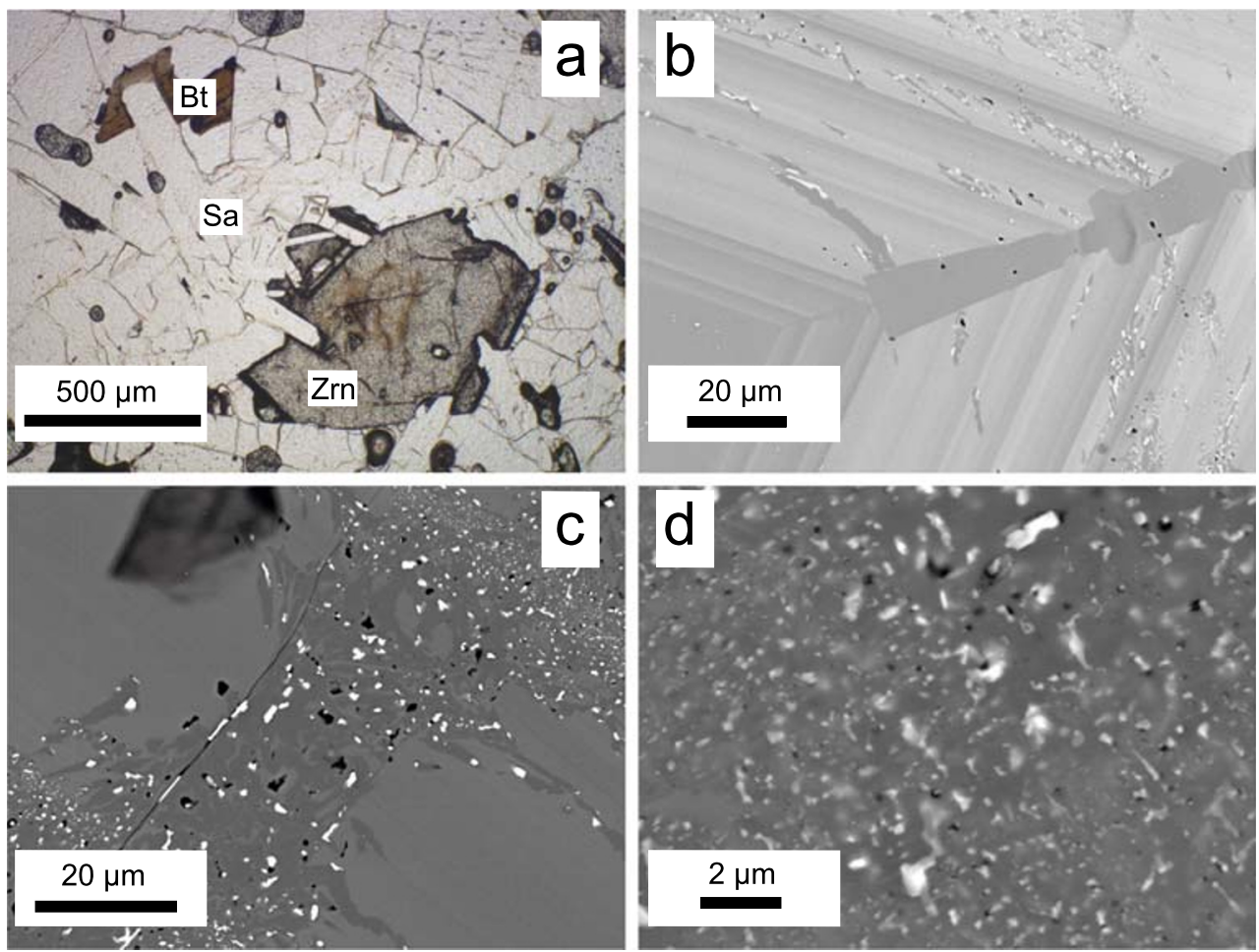
and spectroscopy. These crystals were mounted in epoxy, ground to a uniform thickness between $\sim 200 \mu \mathrm{m}$ and $400 \mu \mathrm{m}$ (depending on crystal size), and polished on both sides. Samples were then removed from the epoxy resin; for easier handling, zircon chips were attached to $2.5 \mathrm{~mm}$ copper rings using a thermoplastic adhesive. After obtaining optical absorption spectra, the adhesive was dissolved in ethanol and the zircon chips were mounted in epoxy (Erc-z2) for further characterization.

\section{Heating and UV irradiation experiments}

Vesuvius and Ratanakiri zircon grains were heat-treated to compare their colour changes during thermal annealing at varying $f_{\mathrm{O} 2}$. The colour stability of the zircon grains under ultraviolet (UV) irradiation was then tested on both heattreated and natural zircon grains. A vertical $\mathrm{CO}_{2} / \mathrm{CO}$ gas mixing furnace by Gero Hochtemperaturöfen $\mathrm{GmbH}$ was used for experiments under reduced conditions. The furnace was held at a constant temperature of $1000{ }^{\circ} \mathrm{C}$ during the course of the experiments, considering $900-1000{ }^{\circ} \mathrm{C}$ as the typical temperature range for commercial heat-treatment of gem zircon as reported in the literature (e.g., Wittwer et al. 2013; Zeug et al. 2018). Zircon grains were placed on a platinum mesh and introduced into the pre-heated furnace. As the exact method for thermal colour enhancement remains secret and further information about the $f_{\mathrm{O} 2}$ conditions used were unavailable (e.g., Zeug et al. 2018), experiments were run at varying $f_{\mathrm{O} 2}$ levels maintained by adjusting the $\mathrm{CO}_{2}: \mathrm{CO}$ mixing ratio (Air Liquide carbon dioxide 4.5, UN 1013; Air Liquide carbon monoxide 3.7, UN 1016) in the furnace. The following mixing ratios were used during the experiments: (1) $\mathrm{CO}_{2}: \mathrm{CO}=60: 40$ vol\%; (2) $\mathrm{CO}_{2}: \mathrm{CO}=80: 20$ vol\%, corresponding to $f_{\mathrm{O} 2}$ near the IW (iron-wüstite) buffer; (3) pure $\mathrm{CO}$, representing the lowest $f_{\mathrm{O} 2}$ achievable using CO-based gas mixing furnaces. Prior to sample removal, the furnace was flooded with pure $\mathrm{CO}_{2}$ for about one minute to prevent the emission of $\mathrm{CO}$. As quenching in cold water could potentially destroy the zircon crystals, samples were directly released from the $1000{ }^{\circ} \mathrm{C}$ hot furnace onto a ceramic plate and immediately transferred into a porcelain crucible for cooling. After a series of initial experiments, single crystals of Vesuvius blue zircon and brown Ratanakiri zircon were heated together in a pure $\mathrm{CO}$ atmosphere at $1000{ }^{\circ} \mathrm{C}$ for $18 \mathrm{~h}$. Heat-treating under oxidizing conditions was carried out in a box furnace, where zircon grains were placed in a platinum crucible and heated for $24 \mathrm{~h}$ at $1000^{\circ} \mathrm{C}$ in ambient atmosphere.

The stability of blue zircon colouration under UV light was experimentally tested for both Vesuvius and Ratanakiri samples, as colour changes of blue gem zircons to light brown under the influence of long-wave UV light have been described before (Renfro 2016). For this purpose, heat-treated Ratanakiri samples and untreated Vesuvius blue zircon were irradiated under both short-wave $(254 \mathrm{~nm})$ and long-wave (365 nm) UV light for ca. $1 \mathrm{~h}$ each using a Vilber Lourmat VL-4.LC with $4 \mathrm{~W}$ lamps.

\section{Optical microscopy}

A Zeiss Stemi 508 stereo microscope with an attached AxioCam ICc1 camera was used to image doubly-polished zircon chips immersed in mineral oil using transmitted and darkfield illumination. Comparison of the colour appearance in both illuminations is a test for scattering, as longwavelength light is scattered less than short-wavelength light, leading to a brownish-reddish tint in transmitted light, and a blueish colour in darkfield illumination (e.g., Pelto 1956). This was verified by imaging a fragment of commercially available synthetic cryolite glass (aka opal glass) under the same conditions, where the variable colour appearance is attributed to light scattering by sub- $\mu \mathrm{m} \mathrm{Ca-}$ and Na-fluoride particles (Ryde and Cooper 1931). A similar test was performed on a piece of blue chalcedony (Fig. S3 in the ESM), another material where blue colouration has been suspected as being due to scattering (Pelto 1956).

\section{Scanning electron microscopy (SEM) and microtomography (micro-CT)}

Epoxy mounts were conductively coated with $3 \mathrm{~nm}$ gold and imaged with a Zeiss EVO MA15 scanning electron microscope equipped with a Gatan ChromaCL2 detector for cathodoluminescence (CL) imaging. Back-scattered electron (BSE) and CL images were obtained from zircon to reveal its internal structure, including growth zones and inclusions. For semi-quantitative elemental analysis using energy dispersive X-ray spectroscopy (EDS) the epoxy mounts were recoated with carbon and analyzed with an Oxford Instruments X$\mathrm{Max}^{\mathrm{N}} 150 \mathrm{~mm}^{2}$ EDS detector on the same instrument. Additional imaging and elemental analysis of heat-treated Vesuvius zircon crystals were performed using a Zeiss Leo 440 instrument equipped with an Oxford Instruments X-Max $80 \mathrm{~mm}^{2}$ EDS detector.

The textural arrangement of inclusions in Vesuvius blue zircon was also visualized using computed microtomography (micro-CT) X-ray analysis using a Carl Zeiss Xradia Versa410 3D X-ray microscope. The instrument was operated with a polychromatic microfocus X-ray source $(150 \mathrm{kV}, 10 \mathrm{~W})$, a $2000 \times 2000$ pixel noise-suppressed charge-coupled detector, and a $10 \times$ objective lens to achieve a resolution of $1.88 \mu \mathrm{m} /$ voxel. 3201 projections over $360^{\circ}$ were generated for the measurement. Attenuation data were reconstructed through a filtered back-projection algorithm using the XRMRe constructor software, producing a stack of 967 cross-sectional, grey-scale digital images that are displayed in animation style (see Animation S1 in the ESM). 


\section{Secondary ionization mass spectrometry (SIMS) and laser ablation inductively coupled plasma mass spec- trometry (LA-ICP-MS) analysis}

Prior to SIMS analysis, the sample was cleaned in an ultrasonic bath following a three-stage cleaning process (ammoniacal EDTA solution, deionized water, and methanol) and a conductive gold layer of $50 \mathrm{~nm}$ thickness was applied to the sample surface. Uranium-Th disequilibrium dating and quantification of selected trace elements (including rare earth elements, REE; Table S1 in the ESM) were carried out by SIMS using a largegeometry CAMECA 1280-HR ion microprobe. A massfiltered ${ }^{16} \mathrm{O}^{-}$primary ion beam was accelerated at $-13 \mathrm{kV}$ to deliver a probe current of $\sim 60 \mathrm{nA}$ at the sample surface. The diameter of the primary beam was $30-40 \mu \mathrm{m}$, and secondary ions were extracted at $+10 \mathrm{kV}$ with an energy bandpass of $50 \mathrm{eV}$. The oxygen-flooding technique (sample chamber pressure $\sim 1.5 \times 10^{-5} \mathrm{~Pa}$ ) was used to increase the production rates of secondary $\mathrm{ThO}^{+}$and $\mathrm{UO}^{+}$ions (Schuhmacher et al. 1994). Secondary ions were detected by Faraday cup (FC; for species with measured intensities $>10^{6}$ counts/s) and axial electron multiplier (EM; for intensities $<10^{6}$ counts/s). Counting times range from 0.5 to $10 \mathrm{~s}$, and intensities for ${ }^{230} \mathrm{ThO}^{+}$were corrected for both background masses 244.026 and 246.3. Background contributions to the measured ${ }^{230} \mathrm{ThO}^{+}$peak range from 1.50 to $2.18 \%$, making the analyses insensitive to background corrections despite the young age of the Vesuvius zircon. All measurements were performed at high mass resolution $(\mathrm{M} / \Delta \mathrm{M})$ of $\sim 7000$. A $\mathrm{U} / \mathrm{Th}$ relative sensitivity factor (RSF) was calibrated on the concordant zircon reference materials AS3 (Paces and Miller 1993; Schmitz et al. 2003) and 91500 (Wiedenbeck et al. 1995, 2004) using common-lead corrected ${ }^{208} \mathrm{~Pb} /{ }^{206} \mathrm{~Pb}$ ratios and the known ${ }^{238} \mathrm{U} /{ }^{206} \mathrm{~Pb}$ ages of the reference zircon samples. Three replicate long-duration measurements gave a mean RSF value of $1.08 \pm 0.02$.

For trace element analysis, an $\sim 4-5 \mathrm{nA}$ beam of ${ }^{16} \mathrm{O}^{-}$primary ions accelerated at $-13 \mathrm{kV}$ resulted in a lateral resolution of $\sim 20 \mu \mathrm{m}$. Energy filtering to suppress molecular interferences was applied using a $-100 \mathrm{~V}$ offset to the nominal acceleration potential of $+13 \mathrm{kV}$ with an energy bandpass of $50 \mathrm{eV}$. Mass resolution was set at $\sim 1800$. The following ions were detected using a single axial EM (major oxide interferences stated in parentheses; single positive ionic charge unless stated otherwise): ${ }^{26} \mathrm{Mg},{ }^{30} \mathrm{Si},{ }^{31} \mathrm{P},{ }^{49} \mathrm{Ti},{ }^{55} \mathrm{Mn},{ }^{57} \mathrm{Fe},{ }^{177} \mathrm{Hf}^{2+}$, ${ }^{89} \mathrm{Y},{ }^{96} \mathrm{Zr},{ }^{139} \mathrm{La},{ }^{140} \mathrm{Ce},{ }^{141} \mathrm{Pr},{ }^{143} \mathrm{Nd},{ }^{149} \mathrm{Sm},{ }^{151} \mathrm{Eu},{ }^{158} \mathrm{Gd}$ $\left({ }^{142} \mathrm{CeO},{ }^{142} \mathrm{NdO}\right),{ }^{159} \mathrm{~Tb}\left({ }^{143} \mathrm{NdO}\right),{ }^{161} \mathrm{Dy}\left({ }^{145} \mathrm{NdO}\right),{ }^{165} \mathrm{Ho}$ $\left({ }^{149} \mathrm{SmO}\right),{ }^{168} \mathrm{Er}\left({ }^{152} \mathrm{SmO}\right),{ }^{169} \mathrm{Tm}\left({ }^{153} \mathrm{EuO}\right),{ }^{172} \mathrm{Yb}$ $\left({ }^{156} \mathrm{GdO}\right),{ }^{175} \mathrm{Lu}\left({ }^{159} \mathrm{TbO}\right),{ }^{178} \mathrm{Hf}\left({ }^{162} \mathrm{DyO}\right),{ }^{232} \mathrm{Th},{ }^{238} \mathrm{U}$. Contributions of light or middle REE (LREE and MREE, respectively) to the measured intensities of the heavier REE species were corrected by peak-stripping using LREE and MREE oxide production rates determined on interferencefree, doped reference glasses prepared after Drake and Weil (1972). NIST SRM 610 (Pearce et al., 1997) was used as the primary reference, and RSF accuracies were tested by analysing 91500 (Wiedenbeck et al. 1995, 2004; Yuan et al. 2007) as a secondary reference; good agreement with published data was found (Fig. 3).
Fig. 3 Chondrite-normalized REE-Y patterns of 91,500 reference zircon and Vesuvius blue zircon. Recommended abundances for CI chondrite by McDonough and Sun (1995) were used for normalization. Note low abundances of heavy REE; variations at $<10$-times chondrite are due to counting errors and not geochemically significant

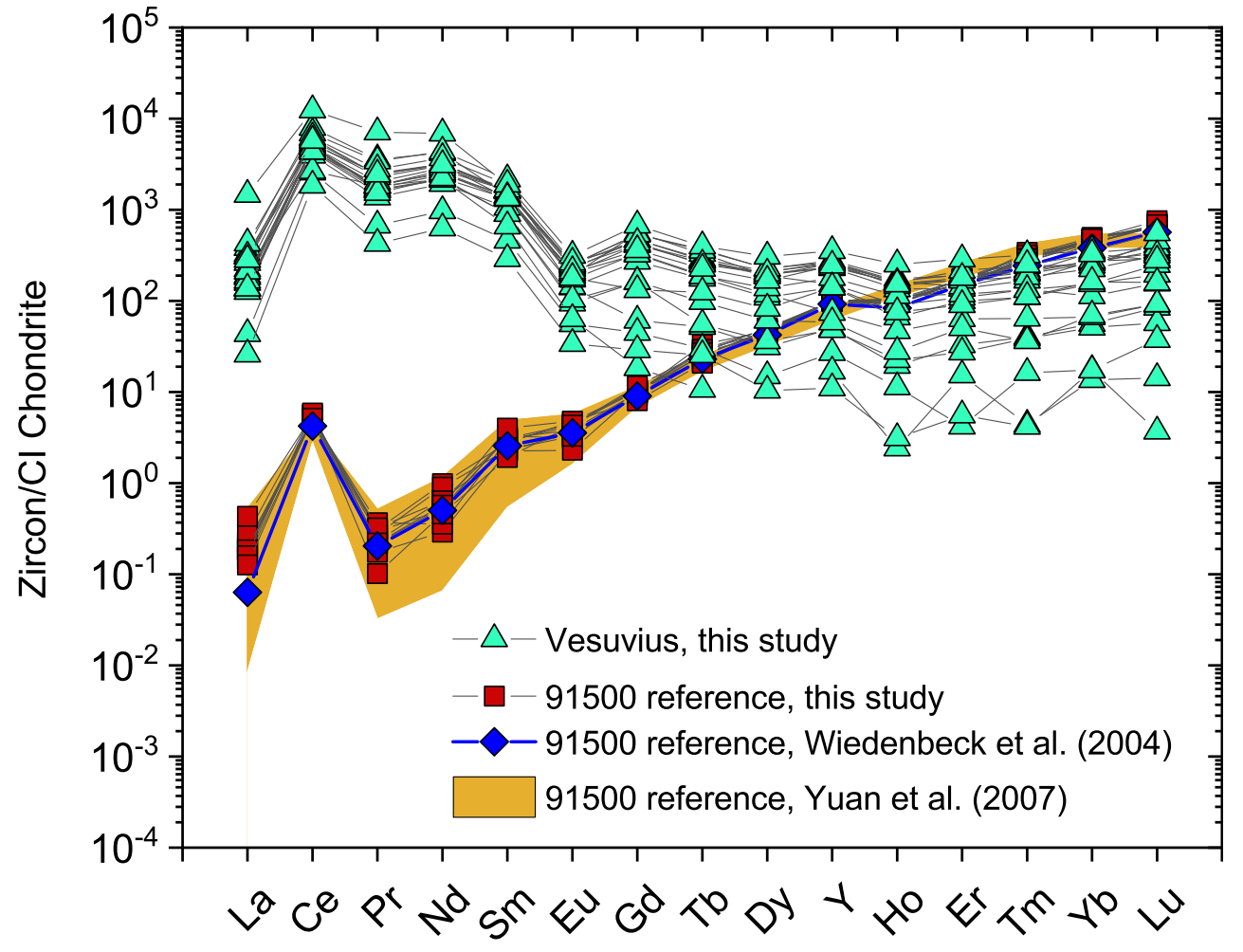


Quantification of $\mathrm{Sc}, \mathrm{Nb}$, and Ta required separate analytical protocols with very high mass resolution $(\mathrm{M} / \Delta \mathrm{M}=$ $\sim 20,000$ ) because the sole or predominant stable isotopes of these elements show isobaric interferences by hydrides and mono- or polyatomic ions: ${ }^{45} \mathrm{Sc}\left({ }^{90} \mathrm{Zr}^{2+}\right),{ }^{93} \mathrm{Nb}\left({ }^{92} \mathrm{ZrH}\right)$, ${ }^{181} \mathrm{Ta}\left({ }^{90} \mathrm{Zr}{ }^{91} \mathrm{Zr}\right)$. Niobium was counted in static multicollection using an axial EM with ${ }^{90} \mathrm{Zr}^{2+}$ as a reference mass on an $\mathrm{FC}$ in the $\mathrm{C}$ position, with the magnetic field regulated at high mass resolution through a nuclear magnetic resonance (NMR) probe. By contrast, Sc and Ta were detected by the axial EM in peak-hopping mode with reference masses ${ }^{90} \mathrm{Zr}^{2+}$ and ${ }^{91} \mathrm{Zr}$ for Sc measured on EM and FC2, respectively, and ${ }^{90} \mathrm{Zr}_{2}$ for Ta measured on the axial EM. For quantification of trace element concentrations, zircon 91500 (Wiedenbeck et al. 1995, 2004) was used as primary reference for standardization of Sc, Nb, and Ta, and Madagascan Green zircon (MAD-559; Coble et al. 2018) served as a secondary reference to assess analytical precision (Table S2 in the ESM). For trace element quantification, $\mathrm{Zr}$ abundances were deduced from the stochiometric composition of zircon. Anomalies for $\mathrm{Ce}$ and $\mathrm{Eu}$ were calculated from chondrite-normalized values as $\mathrm{Ce} /$ $\mathrm{Ce}^{*}$ and $\mathrm{Eu} / \mathrm{Eu}^{*}$ with $*$ marking the theoretically expected abundances from the geometric means of adjacent REE (e.g., Kato et al. 2006).

Oxygen isotopic compositions were analysed by SIMS following procedures in Schmitt et al. (2017). AS3 reference zircon $\left(\delta^{18} \mathrm{O}=+5.34 \%\right.$; Trail et al. 2007) was used to correct for instrumental mass fractionation. Data for 91,500 reference zircon $(+9.63 \pm 0.12 \%$ o, 1 standard error of $n=10$ replicates) placed on the same mount adjacent to the unknowns agree with the nominal value of $+9.86 \%$ (Wiedenbeck et al. 2004) indicating that this correction is reliable. Two spots were placed on each crystal, and the averages of both analysis are reported per crystal in Table S1 of the ESM.

Hafnium isotopic compositions were determined as single spots on 19 zircon crystals (Table S1 in the ESM) using LAICP-MS as described in Gerdes and Zeh (2006, 2009). Accuracy and reproducibility was checked by repeated analyses of reference zircon GJ-1 and Temora for which ${ }^{176} \mathrm{Hf} /{ }^{177} \mathrm{Hf}$ averages of $0.282666(n=14)$ and $0.282008(n=20)$ were obtained in the same session during which Vesuvius zircon was analysed; these values closely agree with published data (Woodhead and Hergt 2005; Gerdes and Zeh 2006).

\section{Raman microspectroscopy}

Comparative Raman microspectroscopy spectra of Vesuvius zircon and inclusions were obtained after cleaning the mount surface to remove all conductive coatings. A Horiba Jobin Yvon LabRAM HR800 Raman spectrometer with a $633 \mathrm{~nm}$ laser source and an 1800 groves/mm grating, and a WITec Alpha 300R Raman microscope featuring a $532 \mathrm{~nm}$ laser source and a UHTS300S spectrometer with a 1200 groves/ mm grating were initially employed because comparison between spectra generated with different laser wavelengths allows the identification of potential spectral artefacts (e.g., photoluminescence). Spectral resolutions for the two systems were $0.8 \mathrm{~cm}^{-1}$ and $2.6 \mathrm{~cm}^{-1}$, respectively. For Raman mapping, a $50 \times$ objective with a numerical aperture of 0.75 was used corresponding to a nominal lateral resolution of $\sim 0.9 \mu \mathrm{m}$ for the $532 \mathrm{~nm}$ laser source. Laser power on the sample surface was $10 \mathrm{~mW}$ for the WITec instrument using the proprietary TruePower readout. The obtained Raman spectra were corrected for cosmic ray interference and background; band fitting used a Voigt algorithm to display FWHM values. Wavenumber calibration was performed using a built-in ArHg lamp which was also used to determine spectral resolution. Gaussian fitting of the $577 \mathrm{~nm}$ emission line yielded a full width at half maximum (FWHM) value of $2.4 \mathrm{~cm}^{-1}$. A value of $2.6 \mathrm{~cm}^{-1}$ was used as the instrument profile function (IPF) to correct bands for spectral broadening using eq. $5 \mathrm{~b}$ from Váczi (2014). The $\sim 1007 \mathrm{~cm}^{-1} v_{3}\left(\mathrm{SiO}_{4}\right)$ Raman band of high-purity synthetic zircon (Guillong et al. 2015) yielded a FWHM of $1.9 \mathrm{~cm}^{-1}$ on the Jobin Yvon LabRAM HR800 (IPF = $0.8 \mathrm{~cm}^{-1}$ ) at $633 \mathrm{~nm}$ and an identical value for the WITec Alpha 300R in agreement with published data (Nasdala et al. 2008a, 2008b). Effective alpha self-radiation doses were calculated for Vesuvius zircon using measured $U$ and Th concentrations, the crystallization age obtained by U/Th isochron dating and the equation by Holland and Gottfried (1955).

\section{Optical absorption spectroscopy}

Optical absorption spectroscopy in the ultraviolet-visible to near-infrared (UV-VIS-NIR) wavelength range was carried out using a J\&M TIDAS UV-VIS-NIR spectrometer equipped with $\mathrm{CCD} / \mathrm{InGaAs}$ detectors and 10× UV-transparent objective lenses. Light sources include a Hg vapor lamp and a xenon lamp, which generated minor spectral artefacts at $656 \mathrm{~nm}, 904-1247 \mathrm{~nm}$, and $1384 \mathrm{~nm}$ in the optical absorption spectra. Each randomly sectioned sample was measured with polarized light at its two extinction positions in cross polarized light. Light intensity without sample was tuned to $70-85 \%$ of detector saturation by adjusting the counting time ( $145 \mathrm{~ms}$ for the UV and visible ranges, $190 \mathrm{~ms}$ for the NIR range), and 100 cycles were measured at each position to improve the signal-to-noise ratio.

\section{Results}

\section{Microtexture, chemical and isotopic composition, and age}

Vesuvius zircon shows oscillatory zoning in all studied grains, with additional sector zoning present in a few crystals, that is 
visible both in BSE and CL images (Fig. 2 b-c; 4 a-c). Microinclusions of mineral phases occur concentrated in vesicle-rich domains where the zircon host is low in BSE intensity. These zones are characterized by low trace element abundances (based on SEM-EDS analysis) and are aligned along crystallographically oriented growth zones or primary cracks (Fig. 2 bc), which were also imaged in three-dimensions for a selected zircon (Animation S1 in the ESM). The inclusions are of either isometric or irregular, elongated shape and exhibit a large variation in grain sizes (Fig. 2 b-d). While a few larger inclusions up to $\sim 60 \mu \mathrm{m}$ in diameter are present, most inclusion dimensions are in the micro- to nanometer range $(\sim 2.5 \mu \mathrm{m}-$ $<<100 \mathrm{~nm}$; Fig. 2 d). Based on combined SEM-EDS and Raman microspectroscopy, the solid inclusions were identified as U-, Th- and REE-rich minerals among which U-bearing thorianite and thorite inclusions are the most abundant. In addition, inclusions of pyrochlore group members are common. Britholite- $(\mathrm{Ce})$ and steacyite $\left(\mathrm{ThNa}_{2} \mathrm{~K}_{1-\mathrm{x}} \square_{\mathrm{x}} \mathrm{Si}_{8} \mathrm{O}_{20}\right.$; with $\mathrm{x} \approx$ 0.5 ; Uvarova et al. 2004) were only identified as rare and comparatively large inclusions. Although SEM-EDS and Raman microspectroscopy methods only permitted identification of inclusions that were at least a few $\mu \mathrm{m}$ in diameter, similar BSE brightness between large and small inclusions suggests that the same phases are also present as small inclusions down to the $<<100 \mathrm{~nm}$ size range (Fig. $2 \mathrm{~b}-\mathrm{d}$ ).

Where homogeneous and with high BSE brightness, the Vesuvius blue zircon crystals contain 59.1-66.3 wt\% $\mathrm{ZrO}_{2}$ and 30.2-34.0 wt\% $\mathrm{SiO}_{2}$. Minor non-stochiometric components include Th (0.7-5.9 wt\%), U (0.3-1.8 wt\%), Hf (3380$5760 \mathrm{ppm}), \mathrm{Nb}(287-3150 \mathrm{ppm})$, and REE, particularly Ce (1131-7610 ppm) and Nd (287-3150 ppm). Phosphorus (25.1-49.1 ppm), Ti (1.68-8.10 ppm), and Ta $(0.44$ $4.51 \mathrm{ppm})$ are present at ppm levels; Sc $(0.06-0.16 \mathrm{ppm})$ and $\mathrm{Mg}$ (up to $0.42 \mathrm{ppm}$ ) were detected in traces. Vesuvius zircon is characterized by unusually flat chondrite normalized REE patterns with a negative slope and high $(\mathrm{Ce} / \mathrm{Yb})_{\mathrm{N}}$ values of 13.3-196 (Fig. 3). While abundances of LREEs are highly enriched relative to CI chondrite by a factor of up to $\sim 10^{4}$, enrichments for MREE and HREE are only between $\sim 20$ and 700 times CI chondrite. Vesuvius blue zircon shows positive $\mathrm{Ce}$ anomalies with $\mathrm{Ce} / \mathrm{Ce}$ * of 3.85-17.6, with La being significantly depleted relative to $\mathrm{Pr}$ and $\mathrm{Nd}$. Characteristic negative $\mathrm{Eu}$ anomalies of $\mathrm{Eu} / \mathrm{Eu}^{*}=0.22-0.58$ exist. Vesuvius zircon shows super-chondritic ratios of $\mathrm{Nb} / \mathrm{Ta}(>37.0)$ and $(\mathrm{Y} / \mathrm{Ho})_{N}=1.40-6.97$.

Zircon $\delta^{18} \mathrm{O}$ averages for individual crystals $(n=20)$ range between +6.5 and $+8.6 \%$ o. The overall variability is about twice that of the reference zircon, suggesting that there is minor heterogeneity. Hafnium isotopic compositions are homogeneous with an average $\varepsilon H f$ value of $-0.4 \pm 0.5$ ( 1 standard deviation, $n=19)$. Vesuvius whole-rock compositions from the literature have values of $\delta^{18} \mathrm{O}=+9.8$ (two nearly identical compositions for Avellino pumice data; Ayuso et al. 1998) and $\varepsilon \mathrm{Hf}=+0.5$ (two nearly identical compositions for Vesuvius mafic lava; Gasperini et al. 2002). The similarity of $\varepsilon \mathrm{Hf}$ between Vesuvius zircon and lava is a strong indication for consanguinity, because zircon faithfully records the Hf-isotopic composition of its parent melt. By contrast, zircon $\delta^{18} \mathrm{O}$ values are at least $1.2 \%$ lower than whole-rock compositions (assumed to be representative of the melt). Model zircon crystallization temperatures $<540{ }^{\circ} \mathrm{C}$ are obtained from $\Delta \Delta^{18} \mathrm{O}_{\text {melt-zircon }}$ as calculated for fractionation factors from Qin et al. (2016) and a melt composition equivalent to Avellino pumice (Ayuso et al. 1998). Such low temperatures are indicative of subsolidus recrystallization rather than equilibrium crystallization at magmatic temperatures.

Vesuvius blue zircon $\left({ }^{238} \mathrm{U}\right) /\left({ }^{232} \mathrm{Th}\right)$ ratios (parentheses indicate activity ratios) range from 0.75 to 1.60 (Table $\mathrm{S} 3$ in the ESM). With $\left({ }^{230} \mathrm{Th}\right) /{ }^{232} \mathrm{Th}$ ) below unity (values ranging from 0.901 to 0.930 ), most analyses plot to the right of the equiline which is defined by a slope of unity and therefore with activity ratios indicating secular equilibrium (Fig. 5). The deviation of the data from the equiline indicates strong $\left({ }^{230} \mathrm{Th}\right) /\left({ }^{238} \mathrm{U}\right)$ disequilibrium in Vesuvius zircon and hence a young age. Linear fitting of all zircon analyses yielded an isochron age of $3.41 \pm$ $0.59 \mathrm{ka}(1 \sigma ; \mathrm{MSWD}=0.81 ; \mathrm{n}=20$; Fig. 5$)$, which agrees with the published eruption age for Avellino pumice (3.95 \pm $0.01 \mathrm{ka} ;{ }^{14} \mathrm{C}$ dating of organic matter within distal fall out units; Sevink et al. 2011) within uncertainties, further underscoring that syenitic ejecta are cogenetic with the erupted phonolite magma.

\section{Colour in optical microscopy}

Cryolite glass imaged as a reference for scattering displays blue streaks in darkfield illumination. These streaks appear orange-brown colour in transmitted light (Fig. $6 \mathrm{a}-\mathrm{b}$ ), whereas transparent domains are black in darkfield. Similarly, some parts of Vesuvius zircon appear blueish-purplish in darkfield illumination (Fig. $6 \mathrm{c}-\mathrm{d}$ ). In contrast to the cryolite glass, some zircon domains are nearly opaque in transmitted light due to abundant inclusions which are larger than those in the glass; where inclusions are absent and light is transmitted, however, the transparent light colour is mostly greyish-brown with weak hints of purple (Fig. 6 c-d). Heated blue Ratanakiri zircon sectioned and polished to the same thickness as the Vesuvius zircon chips is colourless in both transmitted light and darkfield illumination (Fig. 6 e-f).

\section{Colour change under heating and irradiation}

In our heating experiments, the original, dark-brown colour of Ratanakiri zircon vanished after thermal annealing at $950{ }^{\circ} \mathrm{C}$ for $1 \mathrm{~h}$; it could not be restored by subsequent heating, neither under oxidizing nor reducing conditions. Intensities of blue 
colouration in heat-treated Ratanakiri zircon are highly dependent on the individual composition of the grains, as samples from the same experimental runs attained different shades of blue. Regardless, the intensity of the blue colouration generally increased with lower $f_{\mathrm{O} 2}$ and increasing heating duration. The most intense blue colour in Ratanakiri zircon was achieved by heating at $1000{ }^{\circ} \mathrm{C}$ in $100 \% \mathrm{CO}$ atmosphere for $>15 \mathrm{~h}$. Under oxidizing conditions, untreated dark-brown and previously blue Ratanakiri zircon faded to light brown or orange after being heated to $1000{ }^{\circ} \mathrm{C}$ for $24 \mathrm{~h}$ in ambient air, consistent with observations in Zeug et al. (2018).

After heating under oxidizing conditions Vesuvius zircon crystals developed a muddy yellow-brown colour (Fig. 7 a). Heat-treatment under reducing conditions did not induce significantly changes of colouration in Vesuvius blue zircon (Fig. $7 \mathrm{~b}-\mathrm{c})$. The yellow-brown colouration generated by heating under oxidizing conditions is most prominent in inclusion-rich zircon domains (Fig.7 d-h), whereas transparent zircon zones devoid of microscopically visible inclusions still retain a pale blue colouration (Fig. 7 a).

UV radiation had no visible effect (neither short-wave nor long-wave) on the colouration of Vesuvius zircon. By contrast, the blue colour of heat-treated Ratanakiri zircon turned into a slightly brownish hue when irradiated by long-wave UV light (365 nm).

\section{Optical absorption spectroscopy}

Optical absorption spectra obtained from Ratanakiri zircon (a heat-treated blue gem crystal) show a strongly polarized absorption band at $\sim 640 \mathrm{~nm}$ that is typical for blue zircon from Ratanakiri (Zeug et al. 2018) and elsewhere (Fig. 8 a-b). The optical absorption spectra of untreated and heat-treated (both oxidizing and reducing conditions) Vesuvius zircon, however, are characterized by the presence of multiple sharp lines that are typical for zircon rich in actinides and lanthanides (e.g., U, Th, Ce) (Nasdala et al. 2003) and a gentle increase in absorbance towards shorter wavelengths (Fig. 8 c-d; Table S4-5 in the ESM). All major sharp bands can be attributed with $\mathrm{U}^{4+}$ bands (e.g., at $654.0 \mathrm{~nm}, 691.2 \mathrm{~nm}$, and $1115.5 \mathrm{~nm}$ ) detected in U-rich zircon, e.g. Mogok green zircon (Fig. 8 c; http:// minerals.gps.caltech.edu/FILES/Visible/zircon/Index.html; last accessed 10.03.2020). Heated and natural Vesuvius zircon samples share the same spectral characteristics and show minor differences in total intensities, with higher intensities observed for the sample heated under oxidizing conditions and decreased absorption for the sample treated under reduced conditions.

\section{Raman microspectroscopy}

Vesuvius blue zircon shows a FWHM for the $v_{3}\left(\mathrm{SiO}_{4}\right)$ Raman band at $\sim 1007 \mathrm{~cm}^{-1}$ ranging from $\sim 3$ to $\sim 9 \mathrm{~cm}^{-1}$ (Fig. 4 and
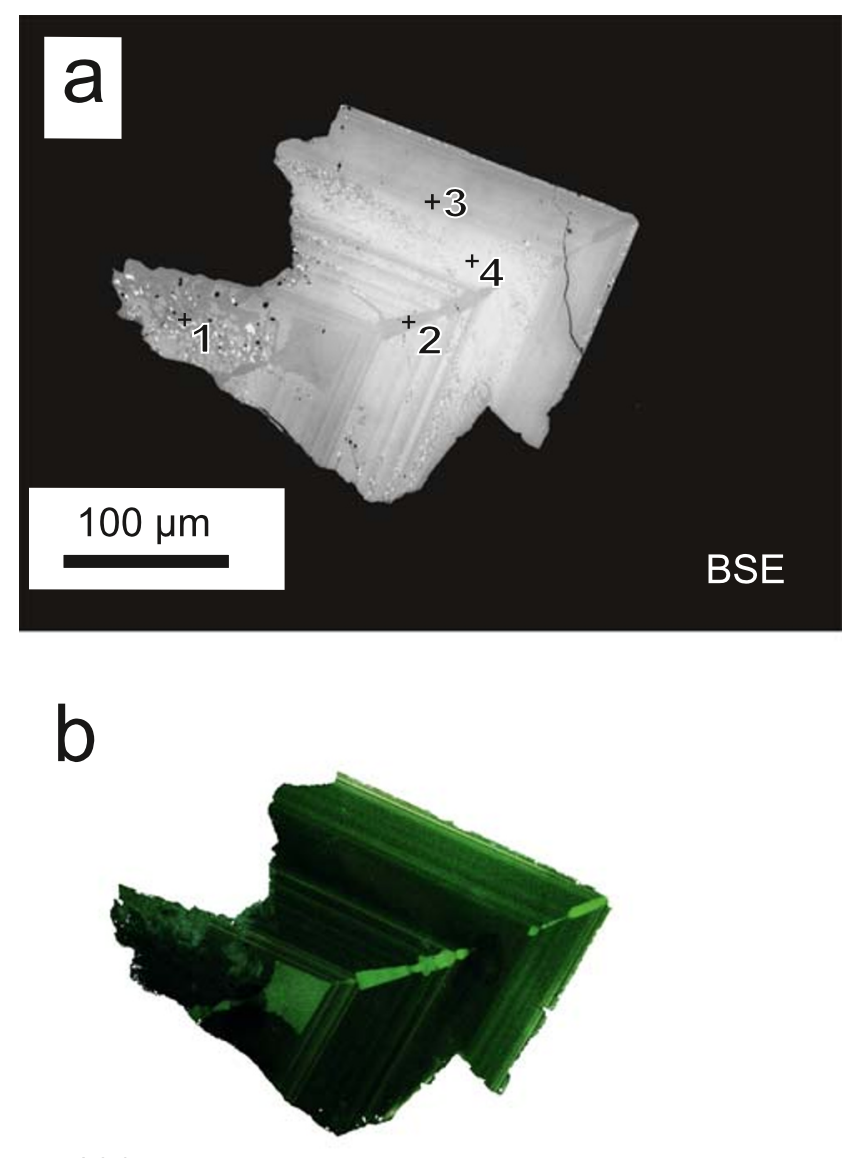

$100 \mu \mathrm{m}$

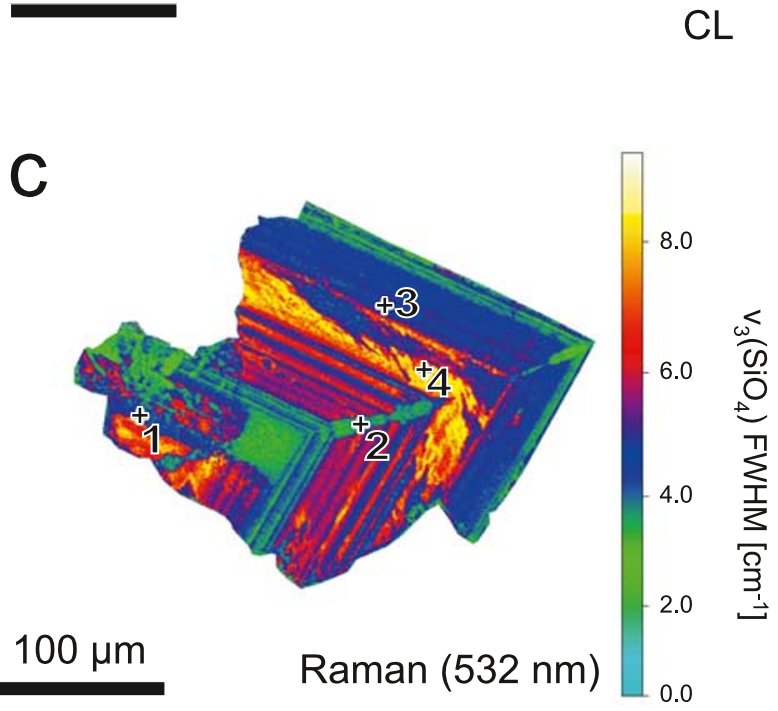

Fig. 4 Overview BSE (a) and CL (b) images of natural Vesuvius zircon (grain 19) showing oscillatory zonation cross-cut by intergrowth of low BSE intensity zircon domains dotted with abundant inclusions showing high BSE intensities. Raman microspectroscopy map (c) generated with a $532 \mathrm{~nm}$ laser using lateral step widths of $1 \mu \mathrm{m}$. Colour scale shows the full width at half maximum (FWHM) of the $\sim 1007 \mathrm{~cm}^{-1} v_{3}\left(\mathrm{SiO}_{4}\right)$ band after correction for spectral broadening. Note the reduction in FWHM in irregular, inclusion-rich zones (especially in the left part of the exposed crystal), as well as in growth domains with high BSE intensities. Crosses are fiduciary marks 
Fig. S4-6 in the ESM). A broad photoluminescence signal causing elevated backgrounds at $\sim 1007 \mathrm{~cm}^{-1}$ is present in some spectra generated with $633 \mathrm{~nm}$ excitation (Figs. S4 and 5 in the ESM at points 1 and 4), but not in the spectra obtained with $532 \mathrm{~nm}$ excitation. Raman microspectroscopy mapping reveals that homogeneous zircon domains high in BSE intensity generally have broader (and possibly split) bands compared to domains low in BSE intensity (Fig. 4 c). Mapping also reveals that the original oscillatory zonation is overprinted by irregular and often cross-cutting zones where the FWHM of the $\sim 1007 \mathrm{~cm}^{-1}$ band is reduced relative to the original domain; these zones are typically inclusion-rich where zircon shows low and inclusions high BSE intensities (Fig. 4). Variations in FWHM for the $\sim 1007 \mathrm{~cm}^{-1}$ band also correlate with a minor shift to lower Raman-shift values e.g. from $1008 \mathrm{~cm}^{-1}$ (low BSE intensity) to $1004 \mathrm{~cm}^{-1}$ (high BSE intensity; Fig. S4-S6 in ESM). Bands are narrowest $\left(\sim 3 \mathrm{~cm}^{-1}\right)$ in domains with large inclusions where zircon has low BSE intensity (point 1 in Fig. 4) and in those with low BSE intensities and no inclusions (point 2). High-brightness BSE domains without inclusions have intermediate FWHM values (point 3), whereas the widest bands $\left(\sim 9 \mathrm{~cm}^{-1}\right)$ were detected in zones where zircon has high BSE brightness, and inclusions are scarce or absent (point 4; see also example spectra for these domains in Fig. S5 in the ESM).

Using Th and $U$ abundances of homogeneous zircon showing high BSE intensities and the U-Th isochron age, an effective self-radiation dose of $2.20 \times 10^{11} \alpha / \mathrm{mg}$ was calculated for Vesuvius zircon. Because of the wt $\%$ level Th and $U$ abundances of Vesuvius zircon, these low effective $\alpha$-doses are owed primarily to minor exposure times to self-radiation due to their very young crystallization age. This calculated dose value is well below the minimum self-radiation dose of $0.1 \times 10^{18} \alpha / \mathrm{g}$ (Zhang et al. 2000, Nasdala et al. 2004) required to induce minute, spectroscopically detectable structural damage in zircon. Therefore band broadening in Vesuvius zircon is not due to accumulated radiation damage (e.g., Nasdala et al. 1998).

\section{Discussion}

As the only naturally occurring blue zircon known, syenitehosted zircon from the Avellino eruption of Vesuvius is a very unusual material whose origins and causes of colour deserve attention. Geochronology and O-Hf isotopic data are consistent with crystallization of zircon from magmas that were consanguineous to the host phonolite. Textural evidence of interstitial zircon growth along with the unusual enrichment in LREE imply late-stage crystallization in highly evolved residual melts in a largely solidified part of the pre-eruptive magma reservoir. Oxygen isotopes are consistent with subsolidus crystallization at conditions significantly below phonolite eruption temperatures of $\sim 800{ }^{\circ} \mathrm{C}$ (Barberi et al. 1981; Balcone-Boissard et al. 2012). In this regard, Vesuvius blue zircon is genetically similar to syenite-hosted
Fig. 5 Uranium-Th isochron diagram for Vesuvius blue zircon. All uncertainties plotted and stated as $1 \sigma$. The plot combines 21 spot analyses on 20 different crystals where homogeneous, inclusion-free domains were preferentially targeted

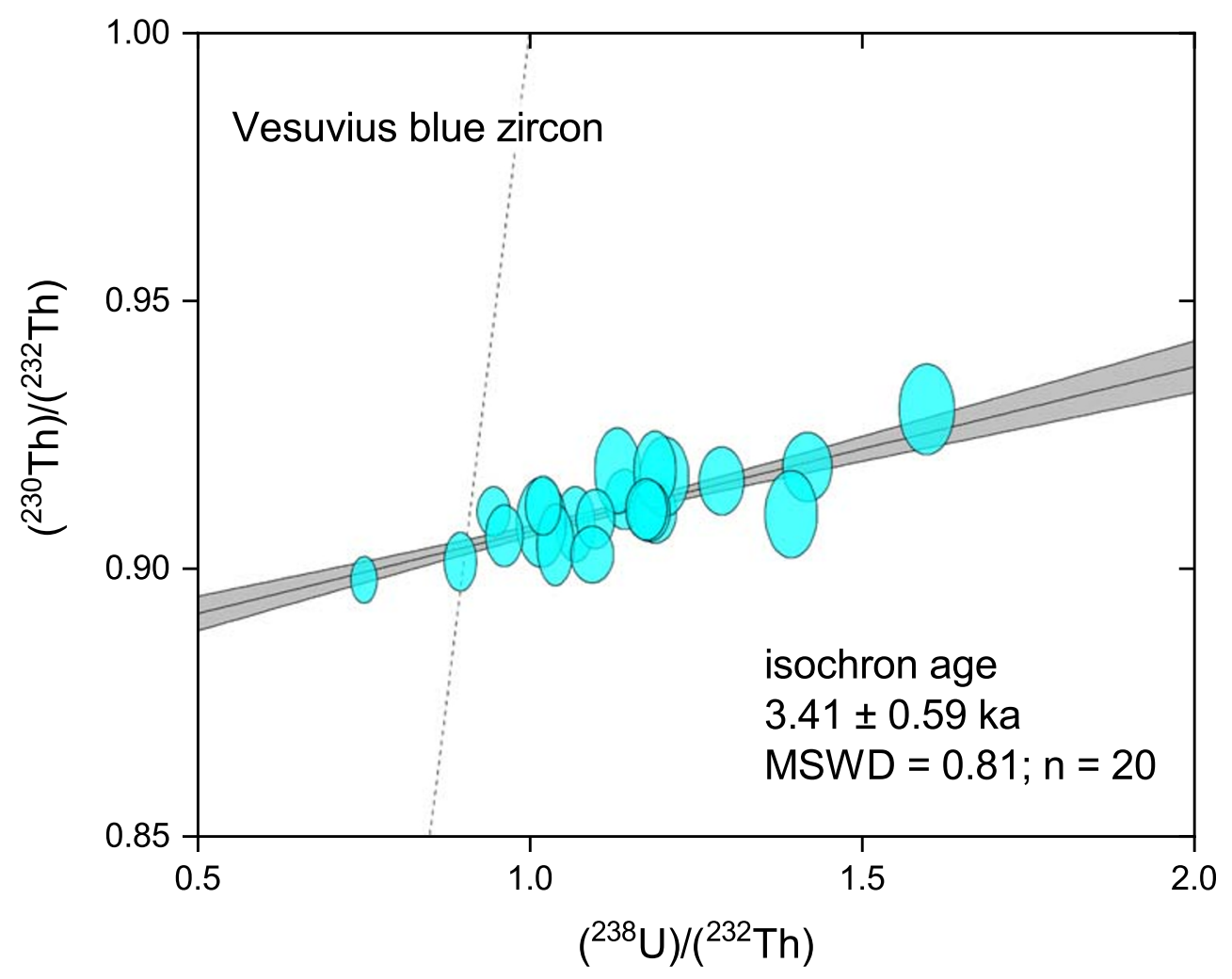



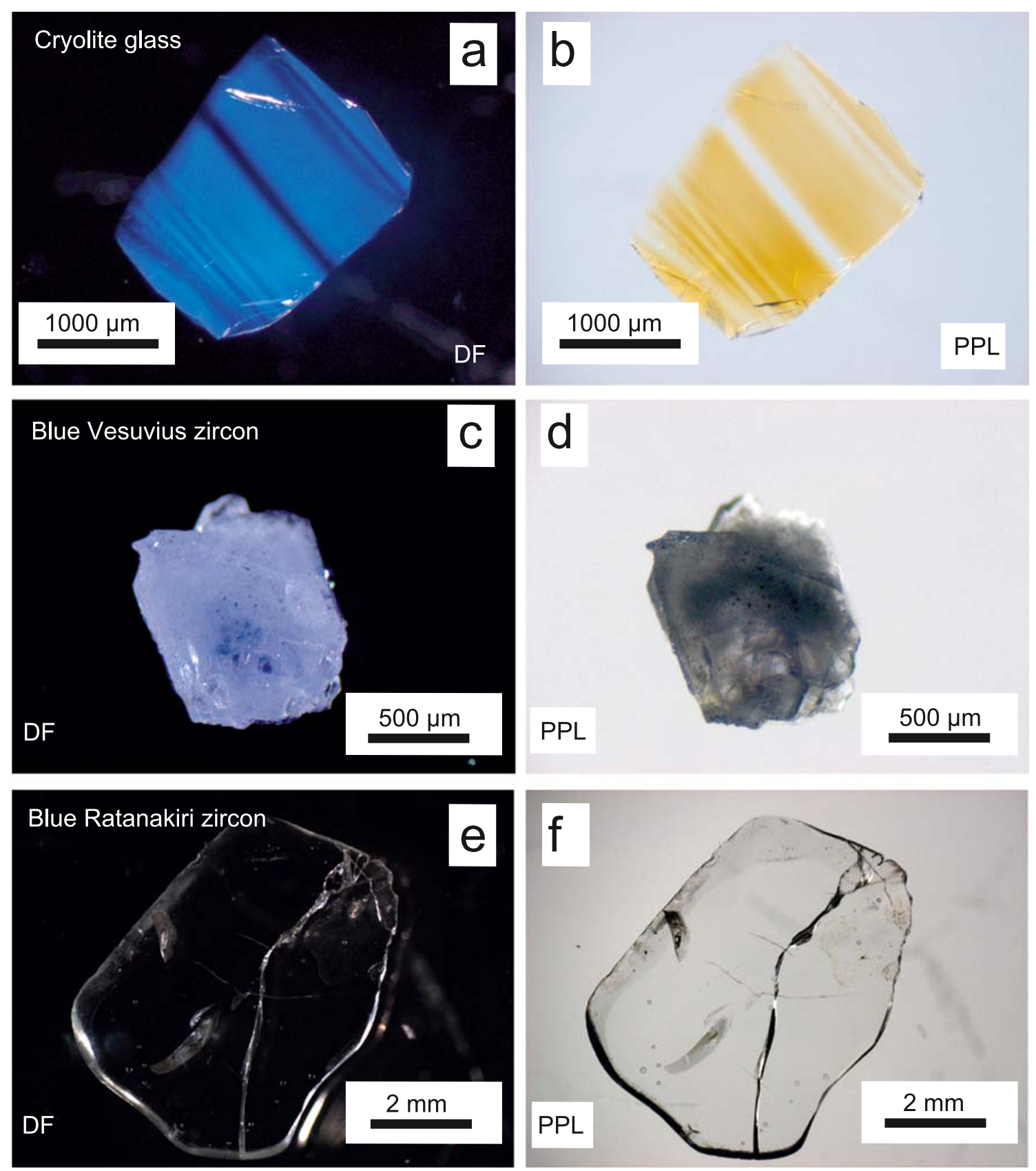

Fig. 6 Darkfield (DF) and plane-polarised transmitted light (PPL) photomicrographs of synthetic cryolite glass (a-b), natural Vesuvius blue zircon (c-d), and blue Ratanakiri zircon, which was heat-treated under reducing conditions (e-f)

zircon from other alkaline magma systems (e.g., Eifel; Schmitt et al. 2017).

Disparate behaviour under long-wave UV, strongly divergent trace element compositions, and prominent differences in optical absorption spectra, suggest that the colouring mechanism for natural Vesuvius zircon must be different from that of heat-treated Ratanakiri zircon. Because the blue colouration of natural Vesuvius zircon remained stable after UV irradiation and heating, electron or hole defects can be ruled out as causes for its colour (e.g., Kempe et al. 2016). Trace elements do not seem to significantly contribute to the colouration of Vesuvius blue zircon either. Vanadium, which is responsible for the

Fig. 7 Vesuvius zircon crystals after heating under (a) oxidizing and (b) reducing conditions. Areas which have remained bluish after heattreatment under oxidizing conditions are marked by dashed lines in (a). Polished thick sections of natural (c) and (d) Vesuvius zircon heat-treated under oxidizing conditions in reflected light (RL) on white background; $\mathrm{e}-\mathrm{f}$ ) the same crystals in PPL on a dark background and $\mathrm{g}-\mathrm{h}$ ) as BSE images. Arrows are drawn as fiduciary markers indicating the orientation of the crystals 

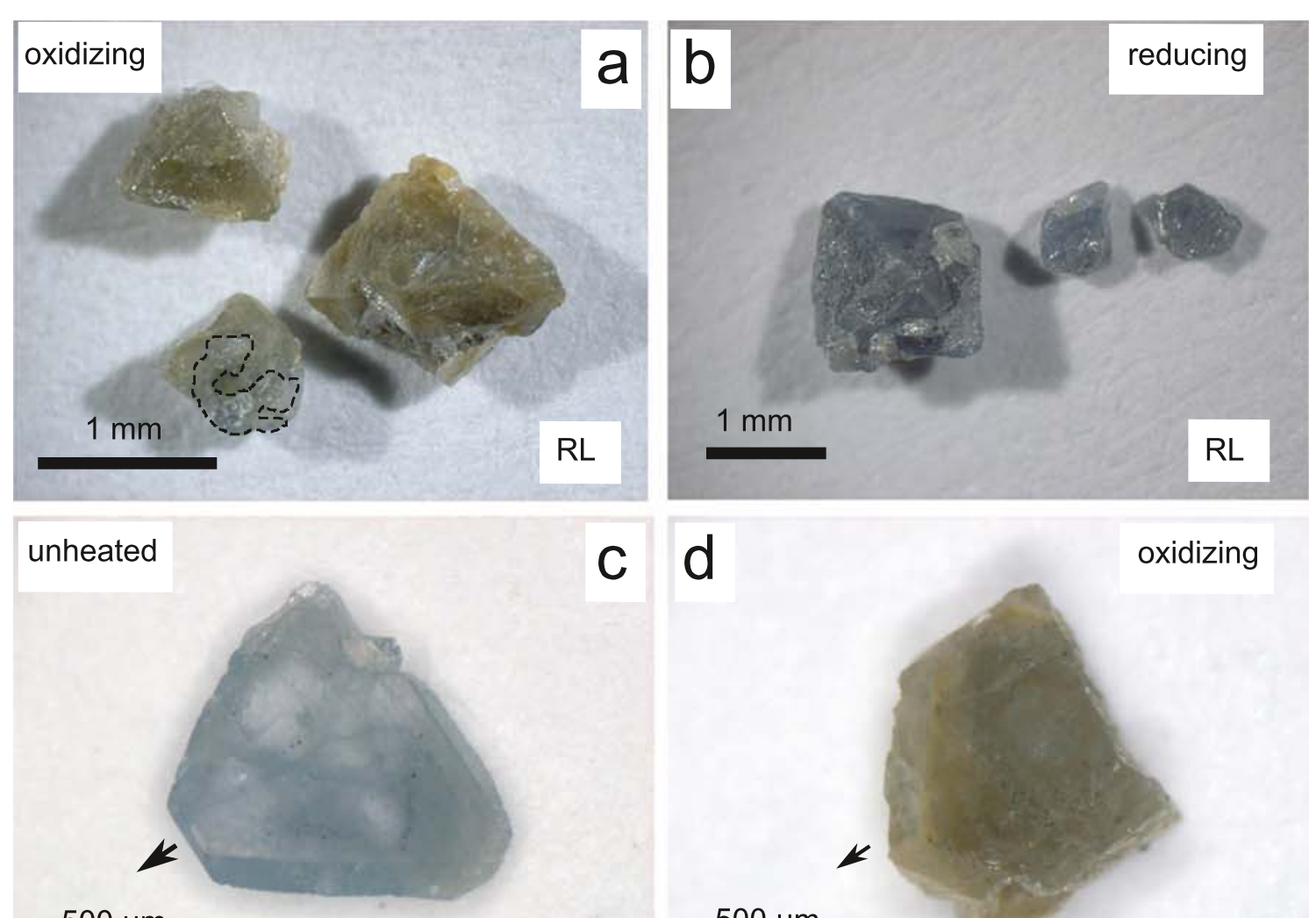

$\mathrm{RL}$

$500 \mu \mathrm{m}$
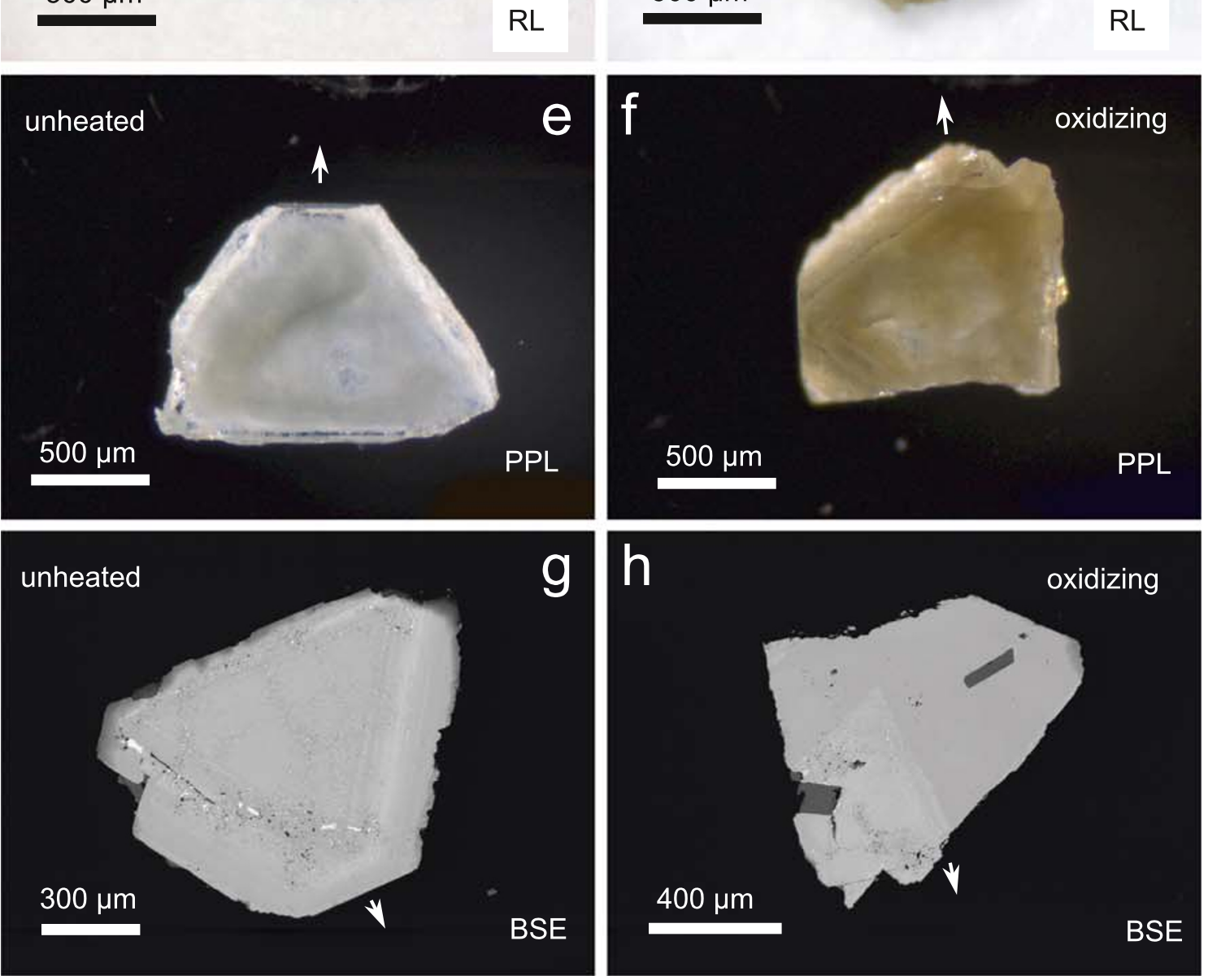
colour of synthetic blue zircon pigment (e.g., Demiray et al. 1970; Waal et al. 1996), is present in concentrations below SIMS limits of detection $(<<1 \mathrm{ppm})$, and absorption bands attributed to $\mathrm{V}$ were not observed in the optical absorption spectra of Vesuvius zircon (Fig. 8 d). Other chromophores typically responsible for blue colouration in minerals (e.g., $\mathrm{Fe}^{2+}, \mathrm{Cu}$ ) are also insignificant in zircon. Synthetic zircon doped with tetravalent $U$ is known to show a purplish-blue colour (Zeug et al. 2018). While $\mathrm{U}^{4+}$ is present in Vesuvius blue zircon at highly elevated concentrations as indicated by optical absorption spectroscopy and chemical analysis, its contribution to the blue colour of Vesuvius zircon is deemed negligible because the most U-rich domains (which lack inclusions) appear nearly colourless in transmitted light (Fig. 6 d).

Instead, we attribute the blue colour in Vesuvius zircon to Rayleigh- and/or Mie-type scattering of incident light by submicrometre-sized inclusions, where long (red) wavelengths are less efficiently scattered compared to short (blue) wavelengths (see review of this effect in minerals by Rossman
2014). Rayleigh scattering occurs for particle sizes considerably smaller (by $<1 / 10$ ) than the wavelength of the incident light, and it is strongly wavelength-dependent; Mie scattering in contrast refers to scattering from particles similar to or larger than the wavelength of the incident light, and it shows a weaker dependence on wavelength than Rayleigh scattering (e.g., Lockwood 2016). Scattering has been cited as the origin of colour in blue quartz, where submicrometric crystallites of rutile, mica or ilmenite are present (Zolensky et al. 1988; Seifert et al. 2011). In corundum, light scattering is caused by rutile micro-inclusions (Wehrmeister and Häger 2006; Krzemnicki et al. 2019).

Other geomaterials where blue colouration has been attributed to scattering include blue chalcedony (Pelto 1956) and moonstone (alkali feldspar; Fritsch and Rossman 1988). In blue zhamanshinite impact glass (Zolensky and Koeberl 1991) and blue-coloured fulgurite (Feng et al. 2019), microspherules of glass formed by liquid-state exsolution are responsible for light scattering and ultimately for the blue colouration (Feng et al. 2019). Previous studies on blue

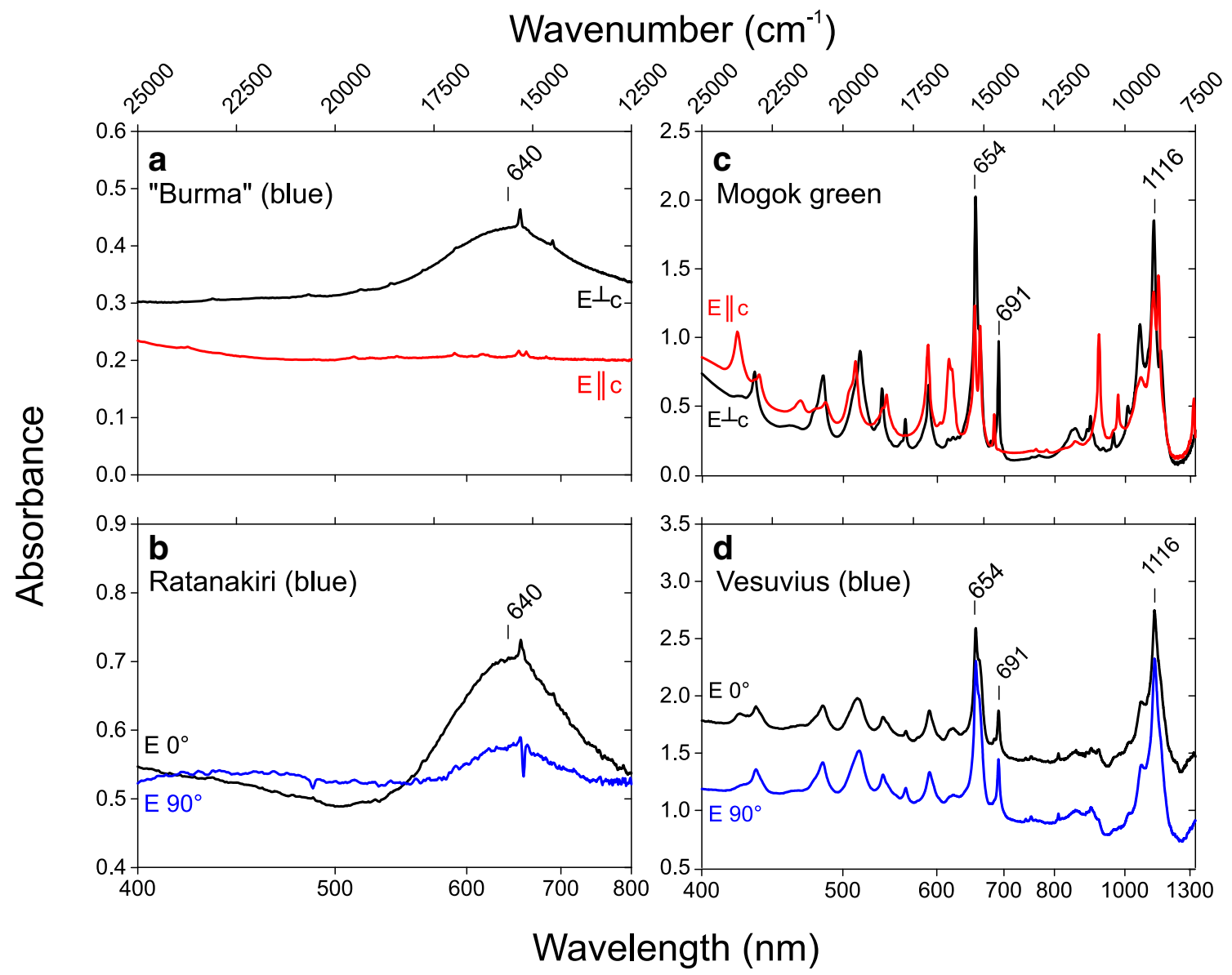

Fig. 8 Optical absorption spectra in the UV-VIS-NIR wavelength range for a) heat-treated "Burma" blue zircon; b) natural and heat-treated Ratanakiri gem zircon; c) natural green metamict zircon from Mogok; d) natural blue Vesuvius zircon. Spectra of Ratanakiri and Vesuvius zircons are in random orientation; spectra were generated in two positions, rotating the specimens by $90^{\circ}$. The marked absorption lines in $\mathrm{c}$ and $\mathrm{d}$ are attributed to $\mathrm{U}^{4+}$. Spectra for "Burma" blue and Mogok green zircon from: http://minerals.gps.caltech.edu/FILES/Visible/zircon/Index.html (last accessed 10.03.2020) 
quartz indicate that a relatively small inclusion density $(0.5-$ 1.7 particles $<55 \mathrm{~nm}$ in diameter per $\mu \mathrm{m}^{3}$ for Llano blue quartz) is sufficient to induce blue colouration in a mineral (Seifert et al. 2011).

Rayleigh and/or Mie scattering is consistent with the blue appearance of Vesuvius zircon because of the following observations: (1) Vesuvius zircon is colourless in transmitted light, and blue only when obliquely illuminated; this is also the case for synthetic cryolite glass whose changing colour appearance is caused by light scattering (Figs. 1 and 6); (2) the blue colouration in darkfield illumination is strongest in domains where nano-inclusions dominate with dimensions smaller than the wavelength of visible light (Figs. 2 and 6); and (3) absorbance generally increases towards shorter wavelengths (Fig. 8). Hence, the ultimate cause for scattering in Vesuvius zircon is the presence of abundant actinide-rich nano-inclusions (e.g., U-rich thorianite), which have a higher index of refraction (n) than the zircon host (e.g., $n=2.11$ for cubic $\mathrm{ThO}_{2}$ and 1.93-1.99 for zircon at $\lambda=589.3 \mathrm{~nm}$; Medenbach and Shannon 1997). These inclusions are heterogeneously distributed throughout the crystals (Figs. 2 and 4); in domains where they are most abundant, inclusion density is estimated to be $>5$ particles of $<100 \mathrm{~nm}$ size per $\mu \mathrm{m}^{3}$ based on high-resolution BSE images (Fig. 2), which is consistent with the inclusion density in blue quartz (Seifert et al. 2011). Because the size of these inclusions continuously extends across the relevant particle sizes for Rayleigh and Mie scattering (Figs. 2 and 6), both processes are expected to contribute to the blue colour appearance of Vesuvius zircon.

Inclusions of Th- and U-rich phases in Vesuvius zircon are always associated with abundant pore space and low BSE intensity zircon domains. This suggests a cogenetic formation by exsolution from primary Th- and U-rich zircon along with a reduction in volume. Similar textures, albeit with a different mineralogy of the inclusion assemblage, have been described for zircon from Island Park-Mount Jackson Rhyolite (Yellowstone, USA) and are interpreted as the result of a coupled dissolution-reprecipitation processes in the presence of hydrothermal fluids (Troch et al. 2018). In this scenario, primary magmatic zircon rich in Th and $U$ becomes metastable upon cooling, causing dissolution along fluid pathways (e.g., fractures) when it resides in a crystalline and fluid-rich part of a magma reservoir. The resulting re-equilibrated assemblage involves secondary zircon with low trace element abundances, as well as Th- and U-rich phases and pore space, effectively minimizing lattice strain in the zircon crystal (Geisler et al. 2007; Troch et al. 2018). This dissolutionreprecipitation process is also supported by the results of Raman microspectroscopy, which shows narrower $v_{3}\left(\mathrm{SiO}_{4}\right)$ bands for the often irregular and vein-like recrystallized domains compared to primary and undisturbed zircon zones (Fig. 4). Narrowing of the Raman band reflects a reduction in lattice strain during recrystallization and formation of more stoichiometrically composed zircon compared to the high actinide abundances in primary zircon. Notably, inclusion formation is less prominent in zircon domains, where primary $\mathrm{Th}$

\section{a Dissolution-reprecipitation}

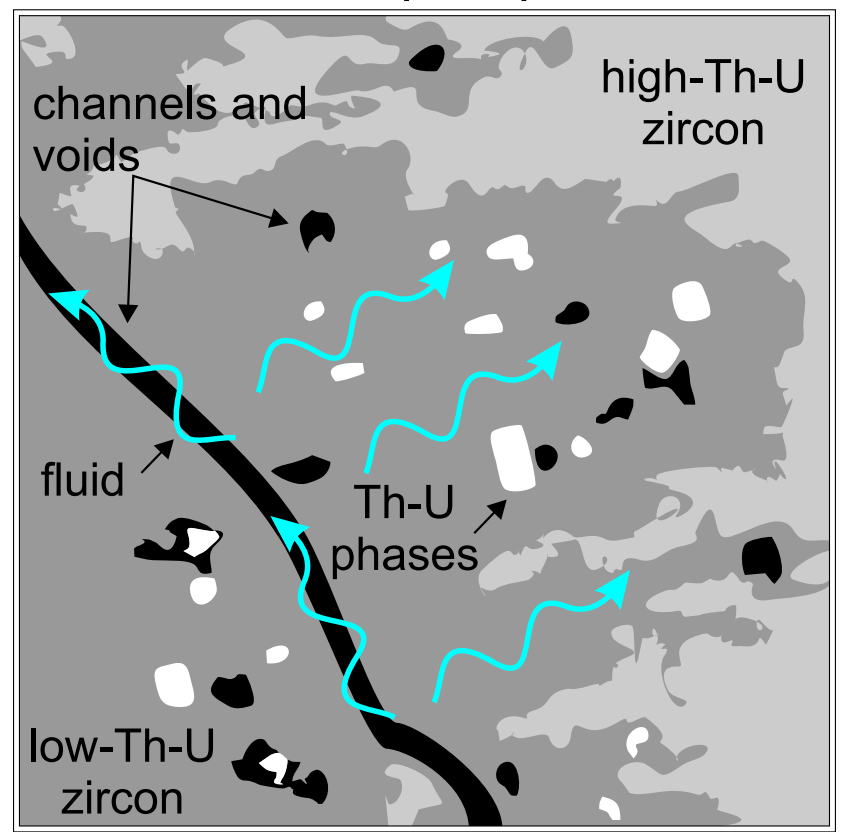

\section{b Light scattering}

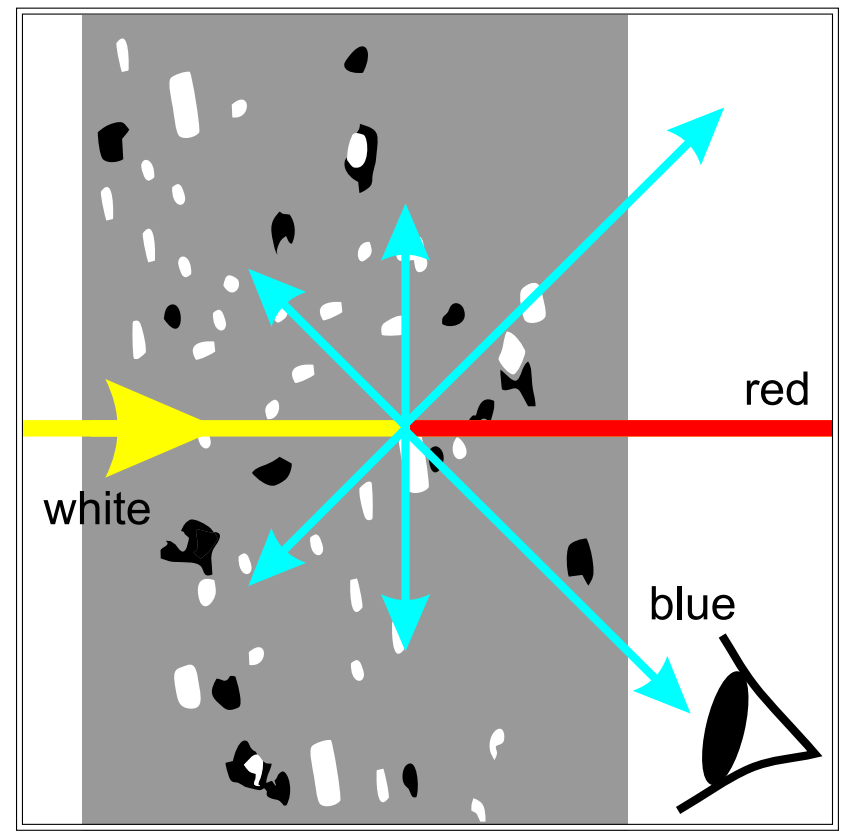

Fig. 9 Schematic summary of the main conclusions: a) formation of ThU-rich mineral inclusions and secondary low-Th-U zircon by dissolutionreprecipitation of primary high-Th-U zircon along fluid pathways; $b$ ) Rayleigh/Mie scattering, preferentially of shorter wavelengths, on numerous tiny inclusions in Vesuvius blue zircon causes blue colouration when viewed in reflected light. In contrast, the zircon appears reddish brown in transmitted light due to the less intense scattering of long (red) wavelengths 
und $\mathrm{U}$ abundances are low as indicated by homogeneously low BSE intensities and comparatively narrow Raman bands (e.g., point 2, Fig. 4. Our preferred model for the formation of Vesuvius blue zircon (Fig. 9) also explains why it is rare in nature: it requires high abundances of Th and/or $U$ to exsolve tiny inclusions, but at the same time these actinide-rich zircon crystals are highly vulnerable to internal radiation damage which produces electron traps and the corresponding brownish red to nearly black ("malacon") colour of zircon (Rossman 1981).

The emergence of a yellowish-brown colouration in inclusion-rich, re-equilibrated zones of Vesuvius zircon after heat treatment under oxidizing conditions remains ambiguous. Scanning electron microscopy and Raman microspectroscopy failed to detect chemical or structural changes in either host zircon or inclusion phases, and inclusions appeared unchanged in frequency, size, and shape after heating. Optical spectroscopy of the brown-coloured domains was not successful due to their poor transparency, resulting in insufficient transmission rates. The most reasonable redox-sensitive chromophore would be $\mathrm{U}^{4+} / \mathrm{U}^{5+}$, as a contribution of $\mathrm{Fe}^{2+} / \mathrm{Fe}^{3+}$ is unlikely based on the low $\mathrm{Fe}$ abundances in zircon and most inclusion phases (e.g., thorianite, thorite) as indicated by SIMS analysis and optical absorption spectroscopy (see spectrum obtained on transparent domains in heated Vesuvius zircon; Table S6 of the ESM). Oxidation of Fe-bearing pyrochlore group minerals, however, is possible as they contain up to $0.5 \mathrm{wt} \% \mathrm{Fe}$ as detected by standardless EDS analyses. Oxidation of $\mathrm{Fe}^{2+}$ and possibly $\mathrm{U}^{4+}$ in inclusion phases is thus tentatively invoked as the cause for the brown colouration of heat-treated Vesuvius zircon.

\section{Conclusion}

Vesuvius blue zircon is an unusual mineral which combines highly elevated concentrations of Th (up to $5.9 \mathrm{wt} \%$ ) and $\mathrm{U}$ (up to $1.8 \mathrm{wt} \%$ ) with low radiation damage due to its very young $(3.41 \pm 0.59 \mathrm{ka})$ crystallization age. Partial dissolution-reprecipitation of originally high-Th and high-U zircon occurred along fractures or internal growth zones prior to eruption, causing exsolution of abundant micro- to nanometre scale mineral inclusions. Rayleigh and/or Mie scattering of light on the smallest of these inclusions is a feasible mechanism to explain the blue colour of Vesuvius zircon. Vesuvius zircon is thus not a natural occurring analogue for heat-treated blue zircon gemstones, which are low in actinides and lack corresponding mineral inclusions that could cause scattering (Zeug et al. 2018).

Acknowledgements We are grateful to Ilona Fin and Oliver Wienand (Heidelberg University) for the preparation of epoxy mounts, thin and thick sections. Alexander Varychev and Jan Schmitt (Heidelberg
University) are thanked for their assistance with the scanning electron microscope and the Raman microscope, and Axel Gerdes (Goethe University Frankfurt) for measuring Hf isotope data. Shuang-Qing Li (Heidelberg University) is thanked for providing sample material of Ratanakiri zircon. Proof reading by Janet Harvey improved the English. Constructive comments by F. Lin Sutherland and two anonymous journal reviewers, and diligent editorial handling by Lutz Nasdala are gratefully acknowledged.

Funding Open Access funding enabled and organized by Projekt DEAL.

Open Access This article is licensed under a Creative Commons Attribution 4.0 International License, which permits use, sharing, adaptation, distribution and reproduction in any medium or format, as long as you give appropriate credit to the original author(s) and the source, provide a link to the Creative Commons licence, and indicate if changes were made. The images or other third party material in this article are included in the article's Creative Commons licence, unless indicated otherwise in a credit line to the material. If material is not included in the article's Creative Commons licence and your intended use is not permitted by statutory regulation or exceeds the permitted use, you will need to obtain permission directly from the copyright holder. To view a copy of this licence, visit http://creativecommons.org/licenses/by/4.0/.

\section{References}

Ayuso RA, De Vivo B, Rolandi G, Seal RR II, Paone A (1998) Geochemical and isotopic $(\mathrm{Nd}-\mathrm{Pb}-\mathrm{Sr}-\mathrm{O})$ variations bearing on the genesis of volcanic rocks from Vesuvius, Italy. J Volcanol Geotherm Res 82:53-78

Balcone-Boissard H, Boudon G, Ucciani G, Villemant B, Cioni R, Civetta L, Orsi G (2012) Magma degassing and eruption dynamics of the Avellino pumice Plinian eruption of Somma-Vesuvius (Italy). Comparison with the Pompeii eruption. Earth Planet Sci Lett 331: 257-268

Barberi F, Bizouard H, Clocchiatti R, Metrich N, Santacroce R, Sbrana A (1981) The Somma-Vesuvius magma chamber: a petrological and volcanological approach. Bull Volcanol 44:295-315

Cioni R, Santacroce R, Sbrana A (1999) Pyroclastic deposits as a guide for reconstructing the multi-stage evolution of the Somma-Vesuvius caldera. Bull Volcanol 61:207-222

Coble MA, Vazquez JA, Barth AP, Wooden J, Burns D, Kylander-Clark A, Jackson S, Vennari CE (2018) Trace element characterisation of MAD-559 zircon reference material for ion microprobe analysis. Geostand Geoanal Res 42:481-497

Deer WA, Howie RA, Zussman J (1982) Rock-forming minerals: orthosilicates, volume 1A. Geological Society of London

Demiray T, Nath DK, Hummel FA (1970) Zircon-vanadium blue pigment. J Am Ceram Soc 53:1-4

Di Renzo V, Di Vito MA, Arienzo I, Carandente A, Civetta L, D'antonio M, Giordano F, Orsi G, Tonarini S (2007) Magmatic history of Somma-Vesuvius on the basis of new geochemical and isotopic data from a deep borehole (Camaldoli della Torre). J Petrol 48: $753-784$

Drake MJ, Weill DF (1972) New rare earth element standards for electron microprobe analysis. Chem Geol 10:179-181

Faulkner MJ, Shigley JE (1989) Zircon from the harts range, northern territory, Australia. Gems Gemol 25:207-215 
Feng T, Lang C, Pasek MA (2019) The origin of blue coloration in a fulgurite from Marquette, Michigan. Lithos 342:288-294

Fritsch E, Rossman GR (1988) An update on color in gems. Part 3: colors caused by band gaps and physical phenomena. Gems Gemol 24(2): 81-102

Fulignati P, Marianelli P, Santacroce R, Sbrana A (2004) Probing the Vesuvius magma chamber-host rock interface through xenoliths. Geol Mag 141:417-428

Gasperini D, Blichert-Toft J, Bosch D, Del Moro A, Macera P, Albarede F (2002) Upwelling of deep mantle material through a plate window: evidence from the geochemistry of Italian basaltic volcanics. J Geophys Res Solid Earth 107:7-19

Geisler T, Schaltegger U, Tomaschek F (2007) Re-equilibration of zircon in aqueous fluids and melts. Elements 3:43-50

Gerdes A, Zeh A (2006) Combined U-Pb and Hf isotope LA-(MC-) ICPMS analyses of detrital zircons: comparison with SHRIMP and new constraints for the provenance and age of an Armorican metasediment in Central Germany. Earth Planet Sci Lett 249:47-61

Gerdes A, Zeh A (2009) Zircon formation versus zircon alteration - new insights from combined $\mathrm{U}-\mathrm{Pb}$ and $\mathrm{Lu}-\mathrm{Hf}$ in-situ LA-ICP-MS analyses, and consequences for the interpretation of Archean zircon from the central zone of the Limpopo Belt. Chem Geol 261:230-243

Guillong M, Schmitt AK, Bachmann O (2015) Comment on "zircon U$\mathrm{Th}-\mathrm{Pb}$ dating using LA-ICP-MS: simultaneous U-Pb and U-Th dating on 0.1 ma Toya Tephra, Japan" by Hisatoshi Ito. J Volcanol Geotherm Res 296:101-103

Holland HD, Gottfried D (1955) The effect of nuclear radiation on the structure of zircon. Acta Cryst 8:291-300

Huong LTT, Vuong BS, Thuyet NTM, Nguyen NK, Satitkune S, Wanthanachaisaeng B, Hofmeister W, Häger T, Hauzenberger C (2016) Geology, gemmological properties and preliminary heat treatment of gem-quality zircon from the central highlands of Vietnam. J Gemmol 35:308-318

Kato Y, Yamaguchi KE, Ohmoto H (2006) Rare earth elements in Precambrian banded iron formations: secular changes of $\mathrm{Ce}$ and $\mathrm{Eu}$ anomalies and evolution of atmospheric oxygen. In: Kesler SE, Ohmoto H (eds) Evolution of early Earth's atmosphere, hydrosphere, and biosphere - constraints from ore deposits, vol 198. Geol Soc Am Mem, pp 269-289

Kempe U, Trinkler M, Pöppl A, Himcinschi C (2016) Coloration of natural zircon. Can Mineral 54(3):635-660

Kostov I (1973) Zircon morphology as a crystallogenetic indicator. Krist Tech 8:11-19

Krzemnicki MS, Butini F, Butini E, De Carolis E (2019) Gemmological analysis of a Roman sapphire intaglio and its possible origin. J Gemmol 36:710-724

Marini L, Chiappini V, Cioni R, Cortecci G, Dinelli E, Principe C, Ferrara $\mathrm{G}$ (1998) Effect of degassing on sulfur contents and $\delta^{34} \mathrm{~S}$ values in Somma-Vesuvius magmas. Bull Volcanol 60:187-194

Medenbach O, Shannon RD (1997) Refractive indices and optical dispersion of 103 synthetic and mineral oxides and silicates measured by a small-prism technique. J Optical Soc Am B 14:3299-3318

Linde N, Ricci T, Shakas A, Berrino G (2017) The 3-D structure of the Somme-Vesuvius volcanic complex (Italy) inferred from new and historic gravity data. Sci Rep 7:1-10

Lockwood DJ (2016) Rayleigh and Mie scattering. In: Encyclopedia of color science and technology. Springer, New York, pp 1-12

McDonough WF, Sun SS (1995) The composition of the earth. Chem Geol 120:223-253

Nasdala L, Pidgeon RT, Wolf D, Irmer G (1998) Metamictization and U$\mathrm{Pb}$ isotopic discordance in single zircons: a combined Raman microprobe and SHRIMP ion probe study. Mineral Petrol 62:1-27

Nasdala L, Zhang M, Kempe U, Panczer G, Gaft M, Andrut M, Plötze M (2003) Spectroscopic methods applied to zircon. In: Hanchar JW, Hoskin PWO (eds) Zircon. Rev Mineral Geochem, vol 53. Miner Soc Am, Washington DC, pp 427-467
Nasdala L, Reiners PW, Garver JI, Kennedy AK, Stern RA, Balan E, Wirth R (2004) Incomplete retention of radiation damage in zircon from Sri Lanka. Am Mineral 89:219-231

Nasdala L, Hofmeister W, Norberg N, Martinson JM, Corfu F, Dörr W, Kamo SL, Kennedy AK, Kronz A, Reiners PW, Frei D, Kosler J, Wan Y, Götze J, Häger T, Kröner A, Valley JW (2008a) Zircon M257- a homogeneous natural reference material for the ion microprobe U-Pb analysis of zircon. Geostand Geoanal Res 32:247-265

Nasdala L, Miletich R, Ruschel K, Váczi T (2008b) Raman study of radiation-damaged zircon under hydrostatic compression. Phys Chem of Minerals 35(10):597-602

Paces JB, Miller JD Jr (1993) Precise U-Pb ages of Duluth complex and related mafic intrusions, northeastern Minnesota: Geochronological insights to physical, petrogenetic, paleomagnetic, and tectonomagmatic processes associated with the 1.1 Ga midcontinent rift system. J Geophys Res Solid Earth 98:13997-14013

Pearce NJ, Perkins WT, Westgate JA, Gorton MP, Jackson SE, Neal CR, Chenery SP (1997) A compilation of new and published major and trace element data for NIST SRM 610 and NIST SRM 612 glass reference materials. Geostand Newslett 21(1):115-144

Pelto CR (1956) A study of chalcedony. Am J Sci 254(1):32-50

Piilonen PC, Sutherland FL, Danišík M, Poirier G, Valley JW, Rowe R (2018) Zircon xenocrysts from Cenozoic alkaline basalts of the Ratanakiri Volcanic Province (Cambodia), Southeast Asia - trace element geochemistry, $\mathrm{O}-\mathrm{Hf}$ isotopic composition, $\mathrm{U}-\mathrm{Pb}$ and (U$\mathrm{Th}$ )/he geochronology — revelations into the underlying lithospheric mantle. Minerals 8:556

Qin T, Wu F, Wu Z, Huang F (2016) First-principles calculations of equilibrium fractionation of $\mathrm{O}$ and $\mathrm{Si}$ isotopes in quartz, albite, anorthite, and zircon. Contrib Mineral Petrol 171:91

Renfro ND (2016) Reversible color modification of blue zircon by longwave ultraviolet radiation. Gems Gemol 52:256-251

Ryde JW, Cooper BS (1931) The scattering of light by turbid media - part II. Proc Royal Soc London Series A 131:464-475

Rossman GR (1981) Color in gems: the new technologies. Gems Gemol 17:60-71

Rossman GR (2014) Optical spectroscopy. In: Henderson GS, Neuville DR, Downs RT (eds) Spectroscopic methods in mineralogy and materials sciences. Rev Mineral Geochem, vol 78. Miner Soc Am, Chantilly, pp 371-398

Rupasinghe MS, Senaratne A (1986) A treatment procedure for improving colour and quality of zircons. J Gemm 20:168-170

Russo M, Punzo I (2004) I Minerali del Somma-Vesuvio. Associazione Micromineralogica Italiana, Cremona, pp 1-320

Santacroce R, Cioni R, Marianelli P, Sbrana A, Sulpizio R, Zanchetta G, Donahue DJ, Joron JL (2008) Age and whole rock-glass compositions of proximal pyroclastics from the major explosive eruptions of Somma-Vesuvius: a review as a tool for distal tephrostratigraphy. J Volcanol Geotherm Res 177:1-18

Satitkune S, Wanthanachaisaeng B, Won-in K, Wongkokau W, Chantararat P, Leelawattanasuk T, Wathanakul P (2013) Heat treatment of zircon samples from Kanchanaburi, Thailand and Ratanakiri, Cambodia. In: Henn U, Zwaan H, Fritsch E (eds) Proceedings of the 33rd international Gemmological conference. Hanoi, Vietnam, pp 158-160

Schmitz MD, Bowring SA, Ireland TR (2003) Evaluation of Duluth complex anorthositic series (AS3) zircon as a U-Pb geochronological standard: new high-precision isotope dilution thermal ionization mass spectrometry results. Geochim Cosmochim Acta 67:36653672

Schmitt AK, Klitzke M, Gerdes A, Schäfer C (2017) Zircon hafniumoxygen isotope and trace element petrochronology of intraplate volcanic rocks from the Eifel (Germany) and implications for mantle versus crustal origins of zircon megacrysts. J Petrol 58:1841-1870

Schuhmacher M, de Chambost E, McKeegan KD, Harrison TM, Migeon $\mathrm{H}$ (1994) In situ U/Pb dating of zircon with the CAMECA ims 1270. 
In: Benninghoven A, Nihei Y, Shimizu R, Werner HW (eds) Secondary ion mass spectrometry SIMS IX. Wiley, Chichester, pp 919-922

Seifert W, Rhede D, Thomas R, Förster HJ, Lucassen F, Dulski P, Wirth R (2011) Distinctive properties of rock-forming blue quartz: inferences from a multi-analytical study of submicron mineral inclusions. Mineral Mag 75:2519-2534

Sevink J, van Bergen MJ, van der Plicht J, Feiken H, Anastasia C, Huizinga A (2011) Robust date for the bronze age Avellino eruption (Somma-Vesuvius): $3945 \pm 10$ calBP $(1995 \pm 10$ calBC). Quat Sci Rev 30:1035-1046

Shao T, Xia Y, Ding X, Cai Y, Song M (2019) Zircon saturation in terrestrial basaltic melts and its geological implications. Solid Earth Sci 4:27-42

Sulpizio R, Cioni R, Di Vito MA, Mele D, Bonasia R, Dellino P (2010a) The Pomici di Avellino eruption of Somma-Vesuvius (3.9 ka BP). Part I: stratigraphy, compositional variability and eruptive dynamics. Bull Volcanol 72:539-558

Sulpizio R, Bonasia R, Dellino P, Mele D, Di Vito MA, La Volpe L (2010b) The Pomici di Avellino eruption of Somma-Vesuvius (3.9 ka BP). Part II: sedimentology and physical volcanology of pyroclastic density current deposits. Bull Volcanol 72:559-577

Trail D, Mojzsis SJ, Harrison TM, Schmitt AK, Watson EB, Young ED (2007) Constraints on hadean zircon protoliths from oxygen isotopes, Ti-thermometry, and rare earth elements. Geochem Geophys Geosystems 8(6):Q06014. https://doi.org/10.1029/ 2006GC001449

Troch J, Ellis BS, Schmitt AK, Bouvier AS, Bachmann O (2018) The dark side of zircon: textural, age, oxygen isotopic and trace element evidence of fluid saturation in the subvolcanic reservoir of the Island Park-Mount Jackson rhyolite, Yellowstone (USA). Contrib Mineral Petrol 173:54

Uvarova YA, Sokolova E, Hawthorne FC, Agakhanov AA, Pautov LA (2004) The crystal structure of arapovite, $\mathrm{U}^{4+}(\mathrm{Ca}, \mathrm{Na})_{2}\left(\mathrm{~K}_{1-}\right.$ $\left.\mathrm{x} \square_{\mathrm{x}}\right)\left[\mathrm{Si}_{8} \mathrm{O}_{20}\right], \mathrm{x} \approx 0.5$, a new mineral of the steacyite group from the Dara-i-Pioz moraine, Tien-Shan mountains, Tajikistan. Can Mineral 42:1005-1011

Váczi T (2014) A new, simple approximation for the deconvolution of instrumental broadening in spectroscopic band profiles. Appl Spectrosc 68(11):1274-1278

Waal DD, Heyns AM, Pretorius G, Clark RJ (1996) Raman spectroscopic investigations of $\mathrm{ZrSiO}_{4}$ : $\mathrm{V}^{4+}$, the blue zircon vanadium pigment. $\mathrm{J}$ Raman Spectrosc 27:657-662
Wehrmeister U, Häger T (2006) Edelsteine erkennen: Eigenschaften und Behandlung. Rühle-Diebener, Stuttgart

Wiedenbeck M, Alle P, Corfu F, Griffin WL, Meier M, Oberli F, von Quadt A, Spiegel W (1995) Three natural zircon standards for U-Th$\mathrm{Pb}$, Lu-Hf, trace element and REE analyses. Geostand Newslett 19: $1-23$

Wiedenbeck M, Hanchar JM, Peck WH, Sylvester P, Valley J, Whitehouse M, Kronz A, Morishita Y, Nasdala L, Fiebig J, Franchi I, Girard JP, Greenwood RC, Hinton R, Kita N, Mason PRD, Norman M, Ogasawara M, Piccoli PM, Rhede D, Satoh H, Schulz-Dobrick B, Skår O, Spicuzza MJ, Terada K, Tindle A, Togashi S, Vennemann T, Xie Q, Zheng YF (2004) Further characterisation of the 91500 zircon crystal. Geostand Geoanal Res 28:9 39

Wittwer A, Nasdala L, Wanthanachaisaeng B, Bunnag N, Škoda R, Balmer WA, Giester G, Zeug M (2013) Mineralogical characterisation of gem zircon from Ratanakiri, Cambodia. In: Nasdala L, Götze J, Hanchar JM (eds) Proceedings of the CORALS-2013: conference on Raman and luminescence spectroscopy in the earth sciences. Austria, Vienna, pp 115-116

Woodhead JD, Hergt JM (2005) A preliminary appraisal of seven natural zircon reference materials for in situ Hf isotope determination. Geostandards Geoanal Res 29:183-195

Yuan W, Bao Z, Dong J, Guo Z, Deng J (2007) Zircon and apatite fission track analyses on mineralization ages and tectonic activities of Tuwu-Yandong porphyry copper deposit in northern Xinjiang, China. Sci China Ser D 50:1787-1795

Zeug M, Nasdala L, Wanthanachaisaeng B, Balmer WA, Corfu F, Wildner M (2018) Blue zircon from Ratanakiri, Cambodia. J Gemmol 36:112-132

Zhang M, Salje EKH, Farnan I, Graeme-Barber A, Daniel P, Ewing RC, Clark AM, Lennox H (2000) Metamictization of zircon: Raman spectroscopic study. J Phys Condens Mat 12:1915-1925

Zolensky ME, Sylvester PJ, Paces JB (1988) Origin and significance of blue coloration in quartz from llano rhyolite (llanite), north-central Llano County, Texas. Am Mineral 73:313-323

Zolensky ME, Koeberl C (1991) Why are blue zhamanshinites blue? Liquid immiscibility in an impact melt. Geochim Cosmochim Acta 55:1483-1486

Publisher's note Springer Nature remains neutral with regard to jurisdictional claims in published maps and institutional affiliations. 